Pamiętnik Literacki 2017, 2, s. 27-53

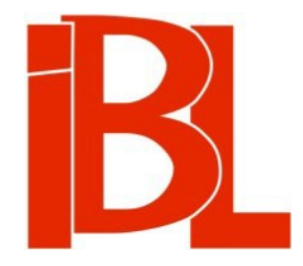

\title{
O „Faraonie” Bolesława Prusa - starożytny Egipt i kontekst polski
}

Adam Eukaszewicz 


\section{O „FARAONIE” BOLESŁAWA PRUSA - STAROŻYTNY EGIPT I KONTEKST POLSKI}

Powieść historyczna jest tylko wypowiedzią na temat przeszłości, a nie jej wiernym odbiciem. Przeszłość zdarzyła się w określony sposób i nie mamy na to wpływu. Nie ma powrotu do przeszłości. Nic na nią nie poradzimy. Niekiedy za mało o niej wiemy albo nasze wyobrażenie o niej jest zgoła mylne. Gdyby ktoś wątpił o tym, że przeszłość naprawdę była i że nie jest tylko złudzeniem, to jej nędzne resztki są wśród nas. Archeologia to sztuka rozpoznawania tych szczątków, które mniej więcej tak się mają do minionej rzeczywistości, jak martwa natura do żywych kwiatów, owoców i zwierząt.

Powieść Bolesława Prusa Faraon nie jest ani wiernym obrazem starożytnego Egiptu, ani artystycznym uzupełnieniem XIX-wiecznej literatury naukowej. Dzieło Prusa otaczała i otacza atmosfera nie zawsze przychylna. Zarzucano mu m.in. „przerosty dydaktyzmu”. W dodatku ekskursy dydaktyczne oraz informacje w zamierzeniu encyklopedyczne rozsiane po całej książce dawno utraciły znamiona użyteczności. Prus jako autor Faraona był i jest w Polsce krytykowany, bagatelizowany i może wręcz skazany na powolne zapomnienie wskutek słabnącego zainteresowania młodszych czytelników.

Natomiast dawniejsi entuzjaści rzekomej wiedzy Prusa o Egipcie byli niefachowcami, a nawet ignorantami w tej dziedzinie. Prusa wszakże trudno winić za ich pełne zachwytu wypowiedzi. Słyszałem, co prawda, że w pewnym polskim ośrodku uniwersyteckim jeszcze niezbyt dawno temu zalecano Faraona studentom historii jako lekturę dydaktyczna, jednak nie wiem, czy wiadomość ta jest ścisła i wiarygodna. Inna sprawa, że bez takich zaleceń ci młodzi czytelnicy może by tej książki w ogóle nie poznali.

Niedawno (w 2014 r.) ukazało się nowe wydanie Faraona, określone w podtytule jako wydanie analityczno-krytyczne ${ }^{1}$. Jest to informacja nieścisła. Wydanie

1 B. Prus (A. Głowa cki), Faraon. Wydanie analityczno-krytyczne z ilustracjami E. Okunia. (Redakcja i projekt graficzny A. Ni wińs ki). Warszawa 2014.

Po tekście powieści znajduje się dodatek Wokót „Faraona”. Eseje uzupetniajace, gdzie opublikowano następujące prace komentujące dzieło Prusa: M. Bierna c ka, Okuń i „Faraon” 1914-2014. - R. Bl e c h, Opus magnum Bolesława Prusa. - H. Ka c z m a r e k: Wiedza o starożytnym Egipcie $w$ Polsce około 1895 roku; Literatura o starożytnym Egipcie $w$ języku polskim z lat 1861-1895. A. N i w iń s ki: Literacka wyprawa Bolesława Prusa do starożytnego Egiptu, czyli „Faraon” okiem egiptologa; Tło historyczne akcji powieści: rekonstrukcja dziejów schytkowej XX oraz XXI dynastii 
krytyczne zawiera tekst ustalony na podstawie całej tradycji rękopiśmiennej i edytorskiej. Variae lectiones podane sa w aparacie krytycznym. W przypadku omawianej edycji Faraona mamy w rzeczywistości do czynienia $z$ wydaniem komentowanym. Faraon w edycji Andrzeja Niwińskiego, znanego badacza starożytnego Egiptu, to dość kosztowny, dotowany przez poważną instytucję, tom dużego formatu, który ukazał się w 500 numerowanych egzemplarzach. Zaletą tego wydania jest zamieszczenie nieprzeciętnych ilustracji przedwojennego artysty-malarza, Edwarda Okunia (1872-1945), publikowanych dotychczas jedynie w postaci (niekompletnego) zestawu pocztówek, dostępnych w Muzeum Bolesława Prusa w Nałęczowie. Okuń był tuż przed wybuchem pierwszej wojny światowej w Egipcie, wysłany tam przez wydawnictwo Gebethnera i Wolffa specjalnie w celu wykonania ilustracji do Faraona. Malował on nad Nilem także inne obrazy i można uznać, że miał wszelkie dane, by uchwycić klimat starożytnego Egiptu i jego sztuki, którą przetworzył na własny, sugestywny sposób.

Reprodukcje ilustracji Okunia w omawianym wydaniu odznaczają się dobra jakością. Redaktor tej edycji, Andrzej Niwiński, aczkolwiek wysoko ceni Faraona, wypomina dyskretnie Prusowi to, że uznawano go niekiedy za autorytet egiptologiczny. Niwiński w swoim komentarzu cytuje te naiwne zachwyty aż nadto obficie ${ }^{2}$. Obok entuzjastów aż roiło się jednak od krytyków, odsądzających Faraona od wszelkiej wartości. Byli wśród nich i współcześni Prusowi adwersarze, był w okresie międzywojennym także znany już wówczas pisarz Jan Parandowski, krytykujący powieść $z$ pozycji autorytetu $\mathrm{w}$ dziedzinie kultury antycznej. Parandowskiego zresztą interesował przede wszystkim klasyczny świat grecko-rzymski i niewątpliwie bliższy od Prusa i Faraona był mu Walter Pater i jego dzieło Mariusz Epikurejczyk.

Nie ulega wątpliwości, że krytycy Prusa maja dużo racji, ponieważ w jego obrazie Egiptu pełno jest błędów. Słusznie wylicza Niwiński anachronizmy, nieścisłości i omyłki Prusa, potępiając np. choćby „metalowa” wannę ${ }^{3}$. W powieści występuje zresztą także wanna kamienna (s. 60). To jednak drobiazg, bo nie wiemy na pewno, jak $z$ tymi wannami było.

Poważniejsze błędy Prusa można by długo wyliczać. Piramidy Starego Państwa zbudowali w rzeczywistości wolni wykwalifikowani robotnicy, a nie tłumy chłopów poganianych kijami. Pod wielkim sfinksem nie było tajemnej świątyni. W Egipcie Ramessydów nie było pieniędzy, wszechpotężnej tajnej organizacji kapłańskiej, ostrego antagonizmu między kapłanami a faraonem, skarbca w Labiryncie, ,armii robotniczej” zorganizowanej na sposób wojskowy (s. 25), fenickich lichwiarzy ani licznych niewolników. Chłopi nie przypominali swym położeniem europejskich chłopów pańszczyźnianych. Podatki w naturze nie były aż tak wysokie, jak uważano w czasach Prusa, i zazwyczaj nie groziły rolnikowi skrajną nędzą. Państwo faraonów, wbrew twierdzeniom pisarza, nie opierało się na nieustannym i powszechnym biciu, przymusie i drakońskich prawach. Asyria w XI w. p.n.e. nie była jeszcze

oparta na źródłach egiptologicznych. - L. Zinkow, Życie pośmiertne faraonów. Odnośniki do stronic Faraona, a także do objaśniających go komentarzy A. Ni w iń s ki e go umieszczam w tekście głównym, natomiast lokalizacje odsyłające do końcowych esejów podaję w przypisach.

2 Niw iń s ki, Literacka wyprawa Bolesława Prusa do starożytnego Egiptu [...], s. 627, 630.

3 Ibidem, s. 632. 
głównym wrogiem Egiptu. Armie nie były w owych czasach aż tak liczne, jak podaje Prus. Wynikało to m.in. z problemów kwatermistrzostwa (czyli tak zwanej dzisiaj logistyki). Liczba ludności Egiptu też była zapewne mniejsza, niż by wynikało $z$ powieści. Nie było machin wojennych $w$ rodzaju urządzeń miotających czy oblężniczych znanych $z$ okresu hellenistycznego. Nie było amfiteatrów (czyli teatrów $\mathrm{z}$ obustronna widownia) ani w ogóle żadnych budowli teatralnych. Nic nie wiemy o przedstawieniach, choć jakieś widowiska $\mathrm{z}$ pewnością miały miejsce.

Ramesses-sa-Ptah to raczej nie faraon Siptah (1195-1189 p.n.e.) z XIX dynastii, bo ten nie mógł być dziadkiem ostatniego $z$ Ramessydów, późniejszego o około 120 lat, mógł natomiast być jego nieco odleglejszym przodkiem. Zapewne chodzi o niedokładnie przytoczone określenie Ramzesa XI (1094-1064 p.n.e.), noszącego przydomek: Setepenptah (,Wybraniec Ptaha”). To Ramzes XI był w rzeczywistości ostatnim faraonem XX dynastii. Numeracja Ramessydów uległa w nauce zmianie od XIX wieku. Ramzes XII i XIII zniknęli z listy królów.

Kapłani nie wygłaszali kazań, nie istniała też spowiedź, polegająca na wyznawaniu popełnionych grzechów publicznie albo wobec kapłana.

Trudno mówić o obecności w Egipcie w czasach późnego Nowego Państwa dobrze rozpoznawalnych potomków Hyksosów, którzy zresztą nie byli jakimś określonym narodem. Termin ten oznaczał 'władców obcych krajów' i odnosił się do królów cudzoziemskiego pochodzenia i podległych im plemion ze wschodu, które na przeciąg jednego stulecia opanowały północną część Egiptu. Nie ma powodu, by dopatrywać się u Egipcjan w owym czasie nietolerancji czy ksenofobii, np. niechęci do Fenicjan i Żydów.

Nie wszystkie rośliny i owoce wymieniane przez pisarza były znane w Egipcie w XI w. p.n.e. Np. konwalie (s. 185) nie występują w Egipcie, a drzewa figowe z powietrznymi korzeniami (s. 45) to figowce indyjskie (Ficus indica), sprowadzone nad Nil w czasach nowożytnych, inne niż dobrze znane w Egipcie drzewka, na których rosną figi jadalne. Podobnie jest $z$ drzewami pomarańczowymi, różami itd. Sprowadzone z Azji kury domowe były już znane w Egipcie, ale w XI w. p.n.e. nie hodowano ich jeszcze na wsi powszechnie (s. 45 i 511). Polowanie było rzeczywiście ulubioną rozrywką faraonów, chętnie polowano z psami, lecz pantera, o której użyciu do łowów wspomina Prus (s. 184), to chyba raczej gepard (niem. Jagdpanther), zwierzę dające się oswoić i ułożyć do polowania. Jazdę wierzchem na koniu znano, ale nieczęsto ją praktykowano. Ubrania rzadko były haftowane. Damy egipskie chyba tylko wyjątkowo paradowały na uczcie $z$ odsłoniętymi piersiami (s. 185), tak swobodny strój mógł natomiast występować u służby. Towarów luksusowych z Azji sprowadzano do Egiptu niewiele. W zasadzie nie było wśród nich złota, bo to właśnie Egipt stanowił jego główne źródło. Egipcjanie nie znali platyny. Rubiny i szafiry oraz perły, diamenty i prawdziwy bursztyn nie występują w znanej biżuterii $z$ okresu Nowego Państwa. Talent był babilońska jednostką wagową, nie zaś jednostką pieniężną używaną w Egipcie Ramessydów. Nie ubierano się w pasiaste stroje, a żołnierze nie nosili ubiorów w pasy żółte i czarne, co z daleka czyniło ich rzekomo podobnymi do wielkich szerszeni. W budownictwie i rzeźbie nie występował marmur (s. 417 i 442). Nie stosowano dekoracji mozaikowej w rodzaju mozaik $\mathrm{z}$ czasów hellenistycznych i rzymskich (s. 185). Fasady domów w miastach nie były dekorowane w sposób opisany przez Prusa (s. 495). Pałace faraonów, wbrew 
przekonaniu występującemu w XIX w., nie przypominały wyglądem świątyń. Na ich dziedzińcach nie było fontann. Rzekomy pałac w Luksorze to świątynia Amona. Miasta funkcjonowały i były zarządzane inaczej niż w Europie. Stolica faraonów XX dynastii nie znajdowała się w Memfis, chociaż było to jedno $\mathrm{z}$ najważniejszych miast egipskich i mieściła się tam także rezydencja królewska. Egipt nie miał sieci bitych dróg lądowych, ponieważ komunikacja odbywała się przeważnie drogą wodną. Nie używano mostów pontonowych (s. 173 i 496). Nie wiadomo nic o istnieniu politycznych ciał kolegialnych, które mogłyby cokolwiek uchwalać w drodze głosowania. Interpretacja politeistycznej i zoolatrycznej religii egipskiej jako swoistego parawanu przeznaczonego do utrzymania ludu w ryzach, a zasłaniającego prawdziwą wiare $\mathrm{w}$ Jedynego Boga, jest daleka od ścisłości. Podobnie ma się rzecz z życiem pozagrobowym i spirytyzmem, pojmowanym przez Prusa zgodnie ze współczesną pisarzowi literaturą. W innym opracowaniu (które ukaże się niebawem $)^{4}$ wspominam, że istnieją powody, by przypuszczać, iż Prus miał jednak w swym księgozbiorze dzieło Adolphe'a d'Assiera Essai sur l'humanité posthume et le spiritisme, par un positiviste (Paris 1883), które dużo później, chyba pod koniec lat sześćdziesiątych XX w., najpewniej nieświadomie, wystawiła w witrynie i niewątpliwie sprzedała komuś księgarnia Gebethnera, mieszcząca się na Pradze przy ulicy Targowej 48. W wieku XIX dość powszechne było mylne przekonanie, że Egipcjanie wierzyli w tzw. wędrówkę dusz (metempsychozę). Sarkofagu faraona kapłani nie wnosili do grobu, ale wciagali, a raczej zsuwali go na płozach. W hypogeach w Dolinie Królów nie było ukrytego okienka.

Również wiadomości o egipskim piśmie, medycynie i astronomii są u Prusa nieścisłe. Nie było „pisma kapłańskiego” (tak mylnie interpretowano kiedyś egipskie pismo hieratyczne) ani tajnego języka zrozumiałego tylko dla kapłanów (rozmowa Herhora $z$ królową na nilowym statku). Skojarzenie pisma chińskiego $z$ "pismem kapłańskim", czyli hieratycznym, to błąd mający w Europie starą tradycję z czasu przed odczytaniem pisma egipskiego. Twierdził tak np. Charles J. de Guignes (1721-1800), który uważał, że Chiny były kiedyś kolonią egipską. W Anglii głoszono wówczas pogląd odwrotny, a mianowicie, że to Egipt był kolonią chińską.

Opis egipskiej szkoły (s. 206) sugeruje realia odmienne od rzeczywistości z czasów faraonów. Zawarcie małżeństwa w Egipcie nie wiązało się z ceremonią religijną. Nazwy miesięcy podawane przez autora weszły w użycie dopiero w czasach późniejszych niż akcja powieści. Sygnalizacja za pomoca choragiewek przypominająca telegraf optyczny i inne praktyki XIX-wieczne, a także znaki dawane lusterkiem nasuwające myśl o tzw. heliografie itd. to arbitralne hipotezy Prusa. Wyobrażenie, że gady kopalne $z$ minionych epok geologicznych mogły się zachować $\mathrm{w}$ jakichś jaskiniach, należy w całości do fantazji pisarza. Do podobnych przejawów licentia auctoris zaliczyć można rzekomą znajomość Indii i Chin przez Fenicjan, potraktowanie sprawy kanału łączącego Morze Śródziemne z Czerwonym jako przedsięwzięcia zbliżonego do Kanału Sueskiego Lessepsa, a także wprowadzenie do fabuły znajomości prochu oraz różnych eksperymentów i praktyk zapowiadających przyszłe wynalazki, np. sakiję (koło z garnkami do czerpania wody), machinę parową

4 A. Łuka szew i cz, Spojrzenie na starożytny Egipt z XIX-wiecznej Warszawy. Na marginesie nowego wydania „Faraona” Bolesława Prusa. „Meander” (w druku). 
i telewizję. Rozmaite sposoby techniczne demonstrowane Ramzesowi przez Pentuera (m.in. użycie swego rodzaju kompasu) to inwencja Prusa.

Wzmianki Prusa o mieszczaństwie i klasach społecznych są oczywiście projekcją pojęć współczesnych pisarzowi. Termin „satrapa” nie był używany do określenia gubernatora prowincji w państwie asyryjskim (s. 270), tylko w późniejszym imperium perskim.

Pisarz z pewnością nie mógł się oprzeć pokusie wprowadzenia do swej powieści pewnych pociagających go myśli. Trudno jednak usprawiedliwiać autora $z$ wyraźnych uchybień wobec ustaleń ówczesnej nauki. Zajmowałem się już gdzie indziej kwestia prawdziwych i rzekomych błędów rzeczowych Prusa ${ }^{5}$.

Przypisy Niwińskiego objaśniają lub korygują większość problematycznych miejsc powieści. Prus nie ponosi odpowiedzialności za znaczną część tych błędów, gdyż wynikły one ze źródeł grecko-rzymskich, ze stanu XIX-wiecznej wiedzy o Egipcie albo $\mathrm{z}$ usterek w rozmaitych, często niefachowych opracowaniach, $\mathrm{z}$ których pisarz korzystał. Może zresztą nie wszystkie źródła jego wiedzy są nam już znane.

Niektóre błędy Prusa pochodzą z publikacji uznawanych w jego czasach za rzetelne opracowania naukowe. Dotyczy to m.in. różnych wersji imion i nazw egipskich. Królowa Hatszepsut np. występuje jako Hatasu nie tylko u Prusa, ale i w kompendiach zagranicznych, choćby w porządnym niemieckim przewodniku po Egipcie z $1874 \mathrm{roku}^{6}$. Sposób i kolejność odczytywania członów w złożonych imionach egipskich bywały w XIX w. odmienne od dzisiejszej, stąd też u Prusa np. imię Ramzesa I (1298-1296 p.n.e.) brzmi Ramenpehuti-Ramessu zamiast Menpehtyre Ramesses. Skądinąd pamiętać należy, że nasza znajomość wymowy staroegipskiej ciagle pozostawia wiele do życzenia. Nazwy miejscowe w powieści odbiegaja nieraz od właściwej postaci. Np. Kaneh (s. 490) to dzisiejsze miasto Kena. Nazwa ta powstała dopiero w czasach, gdy Egipt był prowincją rzymska, i pochodzi od greckiego Kajne (polis), czyli „Nowe Miasto”.

Wiadomości o piśmie egipskim zawarte w książce Prusa są najzupełniej bałamutne, chociaż pod koniec XIX w. istniały już rzetelne publikacje naukowe na temat hieroglifów. Podobnie jest $\mathrm{z}$ interpretacją niektórych symboli, np. uskrzydlonego słońca - nie było ono herbem czy symbolem państwa (s. 63) ani tajemnym symbolem kosmicznym (s. 155).

Parandowski - i nie tylko on - musiał zwrócić uwagę na anachroniczny obraz Greków i Grecji w Faraonie, przywodzący na myśl Grecję klasyczną. Czy jednak wszystkie informacje o Grekach w Egipcie sa w Faraonie nieścisłe? Rzeczywiście, korpus grecki w armii faraonów jest poświadczony dopiero w VI w. p.n.e. W XI w. p.n.e. Grecy nie byli jeszcze uznanymi mistrzami w literaturze, sztukach plastycznych i budownictwie, a taki poglaad wygłasza Ramzes XII w rozmowie $z$ synem. $Z$ drugiej jednak strony, Grecy docierali w owym czasie do Egiptu, co znajduje odzwierciedlenie w Odysei i w greckiej tradycji. W okresie XVIII dynastii sztuka minojska była znana i ceniona w Egipcie, czego dowiodły m.in. niedawne wykopaliska. Mieszkańcy Krety bywali nad brzegami Nilu.

Ibidem.

Zob. A. Graf Proke s c h - O s t e n, Sohn, Nilfahrt bis zu den zweiten Katarakten. Ein Führer durch Aegypten und Nubien. Leipzig 1874, s. 68. 
Wśród obiegowych pojęć, które miały wpływ na obraz Egiptu u Prusa, nie znalazło się tłumaczenie snów. W Egipcie Prusa kapłani, rzecz ciekawa, muszą umacniać uznanie i szacunek ludu dokonując cudów, które są w zasadzie szalbierczymi sztuczkami. Dodajmy, że postać oszukańczego egipskiego sztukmistrza i cudotwórcy należała do stereotypów znanych w literaturze cesarstwa rzymskiego.

W świetle dzisiejszej nauki Faraon nie ma już większej wartości jako kompendium wiedzy o starożytnym Egipcie. Nie znaczy to jednak, że można i trzeba tę powieść poddawać zabiegom adaptacyjnym albo uwspółcześniającej kosmetyce językowej.

W filmie Jerzego Kawalerowicza Faraon z r. 1966 dokonano pewnych ingerencji w fabułę (scenariusz Tadeusza Konwickiego) i w dialogi oraz oprawiono treść scenariusza w znakomitą scenografię, konsultowaną z profesorem Kazimierzem Michałowskim. Dało to w rezultacie udany efekt, choć filmowa adaptacja powieści razi nieco nadmierną surowością niemal wyłącznie pustynnego krajobrazu, sfilmowanego w Kazachstanie i w Egipcie, $\mathrm{z}$ dodatkiem scen na Nilu pochodzacych z Zalewu Wiślanego.

Trzeba zdawać sobie sprawę z faktu, że Prus stworzył z dostępnych mu elementów wiedzy o dawnym Egipcie obraz własny, nie pokrywający się wprawdzie z naszym obecnym stanem nauki, ale urzekajacy w swojej sugestywności. Faraon wprowadza czytelnika w świat wykreowany, który mimo zamierzenia dydaktycznego przyświecającego autorowi nosi przede wszystkim znamiona porywającej artystycznej fantazji. Efekt dydaktyczny utracił aktualność, dramat zachował siłę ekspresji.

Czerpane z rozmaitych źródeł wiadomości o Egipcie Prus uzupełnił elementami wyobraźni i ułożył w system mający cechy kompletności. Egipt przezeń wyimaginowany jest nie mniej ciekawy, bogaty i obfitujący w barwne szczegóły niż Egipt rzeczywisty, chociaż od rzeczywistego nieco się różni. Ze wszystkich powieści wielkiego pisarza Faraon jest książką najbardziej osobistą i zawiera najwyraźniejszą deklarację jego poglądów. Niektóre miejsca powieści zdradzają upodobania Prusa: np. zakłada on umieszczanie ozdób, dekoracji i haftów na ubiorach i przedmiotach codziennego użytku zwykłych ludzi w „lepszych czasach” Egiptu.

Na osobne omówienie zasługuje jedno z głównych nieporozumień „egiptologicznych”, na którym oparta jest fabuła powieści Prusa. Chodzi o rolę kapłanów w państwie i społeczeństwie Egiptu faraonów. Według Prusa był to „zakon mędrców kierujący losami kraju” (s. 26). Prus nie był osamotniony w tym poglądzie ani go nie stworzył.

Wokół kapłanów egipskich od dawna trwają liczne nieporozumienia pochodzące $z$ antycznej erudycji i $z$ niby-naukowej literatury XVIII i XIX wieku. Przedstawiany przez pisarzy antycznych wizerunek kapłanów egipskich ukształtował ich obraz w imaginacji nowożytnej. Istnienie w Egipcie „kasty kapłańskiej” uważano w XVIII w. za pewnik, a źródłem takiego poglądu były dzieła starożytnych autorów greckich, m.in. Herodota, Platona, Pseudo-Kallisthenesa oraz piszacych w okresie rzymskiego i bizantyńskiego panowania w Egipcie np. Heliodora, Horapollona i innych. Towarzyszyła temu chęć zbliżenia się do rzekomej tajemnej wiedzy kapłanów egip- 
skich. Zresztą i w staroegipskich utworach literackich występują czarodzieje ${ }^{7}$, a w Starym Testamencie spotykamy egipskich czarnoksiężników, których w swoistym „konkursie” pokonał Mojżesz (Wj 7).

Tradycyjne przekonanie o mądrości egipskich kapłanów można znaleźć np. w operze Wolfganga Amadeusa Mozarta Czarodziejski flet, która inspirację wzięła z poglądów ówczesnej masonerii na starożytny Egipt i jego tajemną wiedzę. Podobne treści zawiera libretto opery Giuseppe Verdiego Aida, nie tak znowu odległej w czasie od dzieła Prusa, późniejszego zaledwie o ćwierć wieku. Owych wyimaginowanych mędrców egipskich cechować miała nie tylko tajemna wiedza, ale i władza, swoisty esprit de corps oraz złowrogie machinacje.

Jednak w rzeczywistości kapłani nie byli w Egipcie zamknięta grupa, przypominającą kasty indyjskie albo jakieś tajne organizacje. Wielu $z$ nich łączyło funkcje świeckie $\mathrm{z}$ kapłańskimi, mieli żony i dzieci (o tym akurat Prus wiedział). Stanowiska kapłańskie bywały dziedziczone w tej samej rodzinie i przechodziły z pokolenia na pokolenie. Twierdzenia o ascezie praktykowanej przez niektórych kapłanów, o oczyszczaniu się $z$ „brudów świata” (s. 206), o celibacie i postach są anachroniczne, aczkolwiek pojęcie rytualnego oczyszczenia było dobrze znane.

Faraon nie potrzebował święceń kapłańskich czy arcykapłańskich (s. 415), gdyż z natury był najwyższym kapłanem i pośrednikiem między bogami a światem ziemskim.

Kapłani to w Egipcie personel związany ze świątynią i wypełniający czynności kultowe. Świątynia nie była domem modlitwy, ale domem boga, a personel kultowy odgrywał rolę jego sług. Rola ta miała znaczenie kosmiczne, ponieważ spełniając codzienna posługę religijna kapłani zapewniali istnienie i prawidłowe funkcjonowanie wszechświata. Gdyby zabrakło ich rutynowych czynności, światu groziłby powrót do pierwotnego chaosu. W tym sensie sprawowali oni urząd użyteczności publicznej.

Nie wszystko wiemy o czynnościach kapłanów wewnątrz świątyni. Wiadomo, że ściśle regulował je rytuał. Znamy też niemało szczegółów. Świątynia egipska składała się z szeregu pomieszczeń o różnym stopniu dostępności. Sercem świątyni było miejsce najświętsze, niekiedy określane w nauce jako sanktuarium, gdzie mógł wejść w zasadzie tylko faraon albo w jego zastępstwie arcykapłan. Między bogiem a królem zachodziła w Egipcie szczególna więź, czyniąca $z$ władcy strażnika ładu ziemskiego. Ład ten nazywali Egipcjanie „Maat”, co zarazem jest określeniem prawdy, słuszności i sprawiedliwości, jak też imieniem bogini uosabiającej prawdę. Król „czynił Maat”, postępując zgodnie z wolą Re i innych bóstw. Nawiasem mówiąc, obok kultu Amona eksponuje Prus w powieści kult Ozyrysa, traktując go niekiedy jako bóstwo solarne, a przeważnie ( $\mathrm{z}$ wyjątkiem np. s. 511) zapomina o Re, bogu słońca par excellence.

Faraon powoływał arcykapłanów. Każdy kapłan był jedynie zastępcą faraona wobec boga. $Z$ natury rzeczy podlegał więc królowi. Kult grobowy wymagał udziału kapłana w pogrzebie, a w szczególnych przypadkach - stałej działalności kapłanów przez całe pokolenia, modlitw i ofiar składanych zmarłemu albo bogom za pomyśl- 
ność jego duszy. Kapłani byli znawcami i depozytariuszami tekstów liturgicznych, a zatem to oni tworzyli napisy w światyniach i grobowcach, projektowali dekorację tych przybytków, zatwierdzali i nadzorowali wykonanie. Układali i przepisywali teksty eschatologiczne, m.in. Księgę Umarłych. Byli częścią klasy intelektualistów, stanowiącej elitę społeczeństwa, liczaca 1\%, najwyżej 1,5\% ogółu. W pełni znali trudną sztukę pisania oraz literaturę. Autorytet tej grupy brał się $z$ wykształcenia. Jeden z kolegów, badaczy Egiptu, twierdzi, że to właśnie niewielkiej liczebności wykształconej elity cywilizacja egipska zawdzięcza swoje osiągnięcia ${ }^{8}$. Ludzie wykształceni stanowili w Egipcie elitarna grupę odpowiedzialna za kierowanie społeczeństwem i cieszącą się ogólnym szacunkiem. Także faraon musiał być osobą gruntownie wykształconą. W obrębie tego kręgu intelektualistów i skrybów kapłani nie od razu utworzyli oddzielną grupę. Do czasów Nowego Państwa (ok. 1549-1064 p.n.e.) nie stanowili osobnej kategorii społecznej. Za Starego Państwa i Średniego Państwa (III tysiąclecie i pierwsza połowa II tysiąclecia p.n.e.) urzędnicy cywilni pełnili funkcje kapłańskie, niekiedy na zasadzie okresowej delegacji, np. na 4 miesiące, po której wracali do zwykłych obowiązków.

W czasach Starego Państwa (2584-2117 p.n.e.) działalność kapłanów obejmowała dwie sfery: kult bóstw i kult grobowy. W kulcie grobowym poświadczeni sa kapłani „rotacyjni”. Dopiero w okresie Nowego Państwa kapłaństwo stało się zawodem. Wymagane było przygotowanie zawodowe, rytualne oczyszczenie, a nawet ślubowanie. Według znanego niemieckiego badacza religii egipskiej, Jana Assmanna, tzw. spowiedź negatywna ze 125 rozdziału Księgi Umarłych, o której Prus w Faraonie pisze, że „Jest to jeden z najwznioślejszych dokumentów, jakie zostawiła starożytność” (s. 442, przypis 479$)^{9}$, może zawierać tekst, który pierwotnie był tekstem ślubowania kapłańskiego (są to 42 deklaracje, że się nie popełniło różnych grzechów).

Od Nowego Państwa (a więc po roku około 1549 p.n.e.) kapłani musieli sobie golić głowę i całe ciało. Byli też obrzezani - praktyka ta z czasem zaczęła ich odróżniać od reszty społeczeństwa egipskiego. W Egipcie powszechnie praktykowano obrzezanie, zanim jeszcze Izraelici pojawili się na arenie dziejowej. Herodot pisze, że zwyczaj obrzezania inne ludy przejęły od Egipcjan ${ }^{10}$. Z czasów Starego Państwa znamy wizerunki przedstawiające sceny obrzezania młodzieńców, bez związku ze stanem kapłańskim.

Przepisy higieniczne obowiązujące kapłanów dotyczyły też mycia: jak twierdzi Herodot, który odwiedził Egipt w połowie V w. p.n.e., kapłani co trzeci dzień golili owłosienie na całym ciele ${ }^{11}$ i myli się w zimnej wodzie dwa razy w dzień i dwa razy $\mathrm{w}$ nocy ${ }^{12}$. Przestrzegali również przepisów dotyczących diety. Oczyszczenie wewnętrzne dokonywało się przez żucie soli i sody. Kapłanów obowiązywało czyste ubranie lniane i sandały $z$ papirusu ${ }^{13}$, bez wełny i skóry. Nie było celibatu, ale

Zob. A. Ć wi e k, Hieroglify egipskie. Mowa bogów. Poznań 2016.

Prus w przypisie do tekstu podaje mylnie, że jest to rozdział 75. Jak słusznie zauważa Niwiński, przytaczając ów przypis, może to być błąd drukarski.

H e r o d o t, Dzieje, II 36.

Ibidem, II 36-37.

Ibidem, II 37.

Ibidem. 
stosunki seksualne powodowały stan nieczystości i wymagały puryfikacji przed wejściem do świątyni.

Prus myli się przypisując wszystkim kapłanom noszenie skóry pantery. Stary i biedny kapłan Menes, największy mędrzec występujący w powieści, odziany w brudne łachmany, nosi taką skórę, ale jest ona wyleniała (s. 511). W realiach Egiptu faraonów w skórę pantery ubierał się kapłan zwany „sem”. W powieści Prusa imię jednego z nielicznych sympatycznych arcykapłanów brzmi właśnie: Sem, ale to nieporozumienie. Pierwotnie rolę, jaka przypadała w rytuale pogrzebowym kapłanowi sem, pełnił syn zmarłego, celebrujący tzw. rytuał otwarcia ust. Dlatego w grobie Tutanchamona jego następca Ay przedstawiony jest jako celebrans w skórze pantery. Można przypuszczać, że kapłan sem nie nosił tej skóry stale, ale tylko jako szatę liturgiczną na czas celebracji. Istniały też naśladownictwa skóry pantery.

Tytuł „boski ojciec” pierwotnie oznaczał najwyższych kapłanów. Potem była to kategoria pośrednia między „sługą bożym” a „czystym”. W okresie późnym termin „wab [czysty]" stał się ogólnym określeniem kapłanów tych dwu ostatnich kategorii.

Osobny rodzaj stanowili kapłani ze zwojem (chery-hebet), recytujący formuły liturgiczne. Nosili oni szarfę przez pierś. Byli to kapłani zawodowi wysokiej rangi.

Personel światynny, niekiedy bardzo liczny, spełniał rozmaite funkcje kultowe. Wielu kapłanom powierzano funkcje naukowe, edukacyjne i lekarskie w tzw. Domu Życia. Ważną rolę odgrywali kapłani kultu grobowego. Oprócz kapłanów świątynie miały liczący wiele osób personel niekapłański. Byli to rolnicy uprawiający ziemie świątynne, pasterze i hodowcy, ogrodnicy, pszczelarze, myśliwi, rybacy, karmiciele zwierząt, masztalerze, woźnice, oślarze, różni rzemieślnicy, kowale, metalurdzy, szkutnicy, stolarze, tkacze, koszykarze, powroźnicy, garncarze, budowniczowie, olejarze, wytwórcy wina, perfum, piwowarzy, piekarze, rzeźnicy, kucharze, dostawcy wody, łaziebni, muzykanci i śpiewacy, malarze, rzeźbiarze i złotnicy, kamieniarze, krawcy, szewcy i rymarze, rozmaici robotnicy, tragarze, gońcy, sprzątacze oraz pisarze, urzędnicy, inżynierowie, mierniczy, stróże, magazynierzy, kapitanowie, sternicy i załogi statków.

Nad tym całym personelem kultowym i pomocniczym w wielkich światyniach zwierzchnictwo sprawował arcykapłan. Arcykapłan nosił tytuł: „główny sługa boży”. Niekiedy określany był jako pierwszy prorok. Towarzyszyli mu zastępcy: drugi, trzeci i czwarty prorok. W niektórych świątyniach używano specyficznych tytułów, np. w Heliopolis, w świątyni boga Re: „najwyższy prorok”, w Memfis (Ptah): „najwyższy naczelnik rzemieślników”, w Tebach: „otwierający bramę niebios” albo „pierwszy sługa boży Amona”.

W Egipcie istniała tendencja do dziedziczenia stanowisk, także arcykapłańskich i kapłańskich. Faraonowie czasem zgadzali się na to, ale niekiedy przeciwdziałali temu - nawet dosyć stanowczo. Za XVIII dynastii na stanowiska arcykapłańskie powołano wielu zawodowych oficerów, żeby rozprawić się z powstawaniem dziedzicznych wysokich funkcji kapłańskich.

Nie było w Egipcie faraonów żadnej centralnej organizacji religijnej, jakiegoś politeistycznego „Kościoła”. Zwierzchnikiem kapłanów i świątyń był faraon.

Pewną trudność w zrozumieniu religii egipskiej sprawiał ludziom XIX w. jej politeistyczny charakter. Sądzono, że tak liczni i dziwni bogowie nie mogli być przedmiotem autentycznej i żarliwej pobożności, chętnie zatem wyobrażano sobie, że 
prawdziwa wiara warstw oświeconych była związana z Jedynym Bogiem. Nie doceniano przekonania wielu starożytnych czcicieli, że bogowie naprawdę istnieją.

Szczególna pozycja tebańskiego boga Amona datuje się od czasów Nowego Państwa, czyli okresu po najeździe Hyksosów. Był to bowiem patron ponownego zjednoczenia kraju i podbojów XVIII dynastii (1549-1298 p.n.e.). Wcześniej, za Średniego Państwa (ok. 2066-1628 p.n.e.), bóstwo to zajmowało już w egipskim panteonie ważne miejsce, jednak daleko mu było do aż takiego znaczenia, jakie przypadło mu w udziale w czasach późniejszych.

Ogromne nadania królewskie dla świątyni Amona w Tebach stanowiły nagrodę za wsparcie boga dla dynastii. Jednak potężni władcy XVIII i XIX dynastii nie byli uzależnieni od kapłanów. Przekonanie o konflikcie strukturalnym kapłanów i faraona wyrosło m.in. na podstawie wyjątkowej sytuacji: tzw. herezji amarneńskiej, która była czymś zupełnie niesłychanym. Amenhotep IV (1360-1343 p.n.e.), opierając się zreszta na koncepcjach pochodzących od swego ojca, Amenhotepa III (1388-1348 p.n.e.), z którym zapewne przez jakiś czas panował wspólnie, sam zanegował związek dynastii z bogiem Amonem. Zawarto kompromis, król wyprowadził się do nowego miasta Achetaton, ale stamtąd naprawdę rządził państwem i prześladował kult Amona. Prus wiedział, może niezbyt dokładnie, o działaniach Amenhotepa IV, łącząc go $z$ kultem Re Harmachisa (s. 463), co niewątpliwie wzięło się z ówczesnej literatury popularnonaukowej. Odkrycia w El-Amarna były wtedy najświeższymi nowinami archeologicznymi z Egiptu. Przypisywano Achenatonowi (Amenhotepowi IV) solarny monoteizm, ale, jak wiemy dzisiaj, ten czciciel słonecznej tarczy tolerował też niektóre inne kulty. Rzekomy pacyfizm faraona-reformatora okazał się naukową legendą. Był to w rzeczywistości wojujący fanatyk religijny. Po jego śmierci kapłani Amona zemścili się na nim, niszcząc jego imię i likwidując „heretycki” kult Atona - tarczy słonecznej. Pozostali jednak wierni dynastii. Wystapienie kapłanów przeciw domowi panującemu czy ustrojowi państwa było nie do pomyślenia. Rzekomy „prosty kapłan Ey” (s. 463), czyli Ay, który został następcą nie tyle Amenhotepa IV, ile jego syna Tutanchamona, był teściem Amenhotepa, a zatem członkiem rodziny.

Trzeba podkreślić, że Nowe Państwo przyniosło zmianę w strukturze organizacyjnej kapłanów, a zwłaszcza kapłanów Amona tebańskiego. Kult Amona nabrał charakteru szczególnego, związanego z dynastią i z samą istota państwa. Kapłani Amona utworzyli rozległą i potężną strukturę, nie tylko kultową, ale i gospodarczą. Świątynia Amona zgromadziła ogromne bogactwa płynące $z$ darów królewskich. Ten aspekt stosunków między faraonem a kapłanami i świątyniami w okresie wczesnej XX dynastii (za panowania Ramzesa III) został przez Prusa przedstawiony najzupełniej ściśle. Polski pisarz znał już (pośrednio) dane pochodzące $z$ wielkiego papirusu Harrisa. Za Ramzesa III trzy największe świątynie w Egipcie miały łącznie około 100 tys. personelu płci męskiej: dominium Amona z ośrodkiem w Karnaku zatrudniało 81322 mężczyzn, świątynia Re w Heliopolis 12963 mężczyzn, świątynia Ptaha w Memfis 3079 mezżczyzn. Oprócz tego był w świątynnym gospodarstwie bardzo liczny personel żeński.

W świątyniach składano ogromną ilość ofiar i wotów. Mamy wykaz ofiar z kwiatów w wielkiej świątyni Amona obejmujący okres 1057 dni: w tym czasie złożono bogu wieńce, bukiety i pojedyncze kwiaty, razem 4786184 dary. Były też dary 
bardziej kosztowne. Kiedy Asyryjczycy w VII w. p.n.e. ograbili świątynię Amona, zabrali stamtąd 800 ton złota.

Wszystkie te fakty wskazują wprawdzie na rosnące bogactwo i potęgę świątyń, ale nie oznaczaja jeszcze, że faraon był z tego powodu uzależniony od kapłanów, chociaż pod koniec Nowego Państwa, czyli w okresie, w którym rozgrywa się akcja powieści Prusa, doszło rzeczywiście do niezwykłego wzrostu potęgi kleru Amona i znacznego osłabienia pozycji władcy. Herhor (1075-1069 p.n.e.) osiagnął godność arcykapłana Amona na mocy wyroczni, czyli został rzekomo powołany przez samego boga i uzyskał nawet (najzupełniej wyjątkowo) tytuły królewskie (jednak bez realnej władzy nad całym krajem). Karierę poprzedzająca panowanie nad Tebami Herhor zrobił w wojsku. Zmarł przed współczesnym mu władcą Ramzesem XI ${ }^{14}$. Jak widać, w poglądach Prusa na tzw. stan kapłański w Egipcie w końcowym okresie istnienia Nowego Państwa jest niemało słuszności. W rzeczywistych wydarzeniach politycznych towarzyszacych schyłkowi XX dynastii występowały także inne ważne czynniki, nie tylko faraon i kapłani Amona. Były to zwłaszcza wojsko i władze Dolnego Egiptu, gdzie ambitny faraon Ramzes XI znalazł się z czasem w sytuacji zakładnika panujacego tylko nominalnie. Natomiast nie widzimy mieszania się obcych państw do sytuacji wewnętrznej Egiptu. Na szczęście wśród sąsiadów tego kraju nie było wówczas mocarstw zainteresowanych bezpośrednią ingerencją. Osłabienie prestiżu państwa egipskiego poza jego granicami było jednak niewątpliwym faktem, potwierdzonym przez źródła pisane ${ }^{15}$. Osobne zagadnienie stanowiła sytuacja w Nubii, od wieków podległej Egiptowi. Ogólną cechą ówczesnego układu międzynarodowego była destabilizacja i upadek lub zmierzch dawniejszych mocarstw. Czytelnik powieści mógłby na podstawie zakończenia sądzić, że Herhor był założycielem XXI dynastii i zapoczątkował nowy okres rozkwitu i pomyślności Egiptu, co odbiega od skomplikowanej rzeczywistości politycznej, która zastąpiła Nowe Państwo.

Wizja Egiptu zawarta w Faraonie jest więc mieszaniną twierdzeń słusznych i niesłusznych. Obok błędów rzeczowych są tam liczne trafne obserwacje Prusa. Umiejscowienie końca XX dynastii (1187-1064 p.n.e.) w XI w. przed Chrystusem jest poprawne. Terminy takie jak „Stare Państwo”, używane do dziś, funkcjonują w powieści. Nawiasem mówiąc, jest to tłumaczenie francuskiego „Ancien Empire” i niemieckiego „Altes Reich”, przy czym polski wyraz „państwo” oznacza tyle co „imperium” (np. Empire Français, Cesarstwo Francuskie, w czasach napoleońskich nazywano po polsku Państwem Francuskim).

Autor Faraona występuje przeciwko arogancji i pysze establishmentu, uosabianego w powieści głównie przez kapłanów, ale i przez próżniaczą arystokrację oraz bogatych kupców fenickich. Prus opisuje w ten sposób zjawisko mające miejsce w różnych epokach i kulturach. Prus dobrze rozumiał, że w starożytnym Egipcie $z$ religijnością współistniał sceptycyzm, a nawet drwiny $z$ bogów. W przeciwień- 
stwie do wielkiego pisarza niektórzy badacze jeszcze dzisiaj uważają, że oficjalna religia i eschatologia były bez zastanowienia i zastrzeżeń przyjmowane przez całe egipskie społeczeństwo. Tymczasem w Egipcie obok żarliwej religijności występował także brak wiary, a obok sceptycyzmu inteligenckiego istniało też z pewnością niedowiarstwo ludowe. Czy w przeciwnym razie znaleźliby się złodzieje świętokradczo podnoszący rękę na groby boskich królów?

Prus umieszcza w Faraonie wypowiedź Tutmozisa, stanowiąca interesujący wyraz daleko posuniętego sceptycyzmu religijnego przypisywanego przez autora egipskiej arystokracji. Warto może zacytować istotny fragment tego tekstu:

Kapłani to wymyślili brednie o bogach, w których sami nie wierzą. [...] pisarze oszukują bogów w rachunkach, a kapłani posługują się nimi jak łańcuchem i zamkiem do zabezpieczenia swoich skarbców. [s. 298]

Gdzie indziej (s. 226) mowa jest o tym, że kapłani łudzą prostaków, a święty „wół” (raczej: byk) Apis też jest przedmiotem kapłańskich manipulacji. $\mathrm{Nb}$. racjonalizujące wytłumaczenie kultu świętych zwierząt jako sposobu na ochronę pożytecznych gatunków (s. 490) jest niezgodne ze znacznie bardziej złożona prawdą historyczną.

Konstrukcja fabularna oparta na rzekomym „bluźnierstwie” Sary w pieśni śpiewanej na Nilu wydaje się dość sztuczna. Wynikła ona ze znanej w XIX-wiecznej literaturze kwestii egipskiej genezy religii żydowskiej. Jest to interpretacja biblijnej opowieści o pobycie i wyjściu Żydów z Egiptu. Od czasu, gdy stwierdzono, że imię Mojżesz (Mosze) jest proweniencji egipskiej, mnożyły się rozmaite teorie na temat egipskiego pochodzenia samego Mojżesza i zaczęło się tropienie tradycji egipskich w żydowskiej kulturze religijnej. Jeden z hymnów amarneńskich ku czci Atona odczytanych po odkryciu szczątków stolicy heretyckiego faraona okazał się nadzwyczaj podobny do biblijnego psalmu, ewidentnie późniejszego. W powieści Prusa Żydówka Sara śpiewa w łódce na Nilu pieśń religijną ( $\mathrm{z}$ tekstem pomysłu autora), która okazuje się nader bliska uroczystej tajemnej modlitwy kapłanów egipskich, co ma zapewne konsekwencje dla stosunku kapłanów do Sary i dla jej dalszych losów. Sugestię Herhora, że modlitwa Sary mogłaby sprowadzić na Ramzesa proces o bluźnierstwo, należy zaliczyć do swobodnej inwencji Prusa, związanej z ogólnym klimatem XIX-wiecznego odczytywania kultury egipskiej jako przesyconej rygoryzmem religijnym, reprezentowanym przez bezwzględnych i mściwych kapłanów.

Czary i cuda Beroesa, odgrywające w powieści niemała rolę, to jakoby (tak sądziła Janina Kulczycka-Saloni) jedyny watek irracjonalny nie traktowany przez Prusa sceptycznie ${ }^{16}$. Komentatorka nie zwróciła jednak uwagi na ważne dla powieściowej akcji przekleństwa rzucone na wierną Ramzesowi Sare przez urażonego Fenicjanina Dagona. Magiczne praktyki Fenicjanina spowodowały nawet wyraźne zaburzenia w naturze. Klatwa poskutkowała, czary rzucone przez złego człowieka ziściły się w sposób przerażający. Te niewątpliwe przejawy wiary pisarza w możliwość skutecznych praktyk czarnoksięskich wiążą się $z$ jego zainteresowaniem zjawiskami paranormalnymi i ezoterycznymi, dobrze znanym biografom Prusa, a należącym do okresu powstania Faraona. 
Warto dodać słowo o opisach przyrody Egiptu. Krajobrazy ukazane sa dość trafnie. Ciekawe, że niewiele jest obrazów nieba i gwiazd. Pojedyncze wzmianki zawierają np. nazwę konstelacji Lwa i gwiazdy Regulusa (s. 190), a Chaldejczyk Beroes na widok Wielkiej Niedźwiedzicy, Oriona i Syriusza myśli: „U nas gwiazdy mocniej świecą" (s. 154). Jednak astronomia odgrywa w powieści ważną rolę, wspomniana jest mapa nieba na „złotej tablicy” (s. 490) oraz obserwacje prowadzone przez Menesa i Pentuera.

Opisy przyrody ożywionej są dość wiarygodne jak na autora, który nigdy nie był w Egipcie, a tworzył w czasach bez kolorowej fotografii i filmu. Widać, że Prus dokładał starań, by nadać im charakter elementów realistycznego obrazu starożytnego kraju nad Nilem. W szczegółach zdarzają się błędy. Pojawiają się jelenie i sarny, których w Egipcie nie było, albo nosorożce, które zniknęły na długo przed czasami, w jakich toczy się akcja. Podobnie jest z częścią wymienionych w tekście drzew, o czym już wspominałem. Jednak większość upraw występujących w powieści jest historycznie potwierdzona. Prus wiedział, że w XI w. przed Chrystusem Egipcjanie jeszcze nie oswoili wielbłąda. Każe Ramzesowi i innym wojownikom egipskim jeździć konno, co do niedawna uważano za zjawisko wyjątkowe (jak powiedziano wcześniej), dziś wszakże domyślamy się, że jazda wierzchem zdarzała się w dawnym Egipcie częściej, niż kiedyś przypuszczano.

W powieści „w przebraniu”, i to znakomitej, jaka jest Samozwańczy Neron Liona Feuchtwangera, autor nie wykazuje zupełnie zainteresowania przyroda i tworzeniem kompletnej scenerii. Feuchtwanger opisuje jedynie te elementy scenerii, które są niezbędne do ukazania przebiegu zdarzeń, jakby szkoda mu było czasu na tworzenie fikcji, maskującej właściwe przesłanie powieści. Unika zatem drobiazgowej charakterystyki przyrodniczego tła, może zresztą obojętnego mu emocjonalnie. Prus natomiast postępuje inaczej, a to dlatego, że naprawdę pisze o Egipcie i stara się być rzetelnym odtwórcą rzeczywistości.

Prus nie był chyba wielkim znawcą kulinariów. Umieszcza jednak w Faraonie nieliczne wzmianki o jedzeniu, starając się, by nie były one sprzeczne $z$ ówczesną wiedzą o tym, co można było jeść w dawnym Egipcie. Niesłusznie przypisuje Prus starożytnym Egipcjanom unikanie wieprzowiny. Upodobanie autora do prostych potraw, skądinąd widoczne w Lalce, gdzie Prus drwi sobie $z$ wymyślnego smakoszostwa, dochodzi do głosu także w Faraonie - Ramzes, który przedtem chętnie ucztował, wstąpiwszy na tron domaga się ni stąd, ni zowąd „piwa, tudzież żołnierskiego chleba z czosnkiem” (s. 419). Oczywiście, ten „żołnierski chleb” to projekcja asortymentu pieczywa istniejącego w czasach pisarza. Jednak i w dawnym Egipcie były różne gatunki chleba, chociaż nie wszystkie są nam znane. (Nawiasem mówiąc, piszacy te słowa brał czynny udział w odkopaniu staroegipskiej piekarni, co prawda $z$ okresu o 1000 lat wcześniejszego od akcji Faraona).

Nieścisłości zachęcają do krytyki. Komentarze do realiów i sprostowania błędów Prusa zawarte w edycji Andrzeja Niwińskiego podają ogromną ilość konkretnych informacji wzbogacajacych wiedzę czytelnika. Do objaśniania Faraona wydawca ten wciagnną też innych badaczy przedmiotu. Zestawiono polską bibliografię z czasów Prusa dotycząca Egiptu oraz sporządzono wykaz dzieł, z których pisarz korzystał. Nadzwyczaj wartościowe uwagi uczonego znawcy Egiptu nie sa jednak całkiem 
wolne od tez dyskusyjnych ${ }^{17}$. Można się np. zastanawiać nad słusznością przekonania Niwińskiego, że Prus podając we Wstępie temperatury w Egipcie (s. 24) posługuje się skalą Réaumura. Jeśli „niekiedy gorąco sięga czterdziestu siedmiu stopni" (s. 24), to jest to zgodne z rzeczywistymi maksymalnymi temperaturami w stopniach Celsjusza w cieniu w pełni lata, gdy tymczasem temperatura 47 stopni Réaumura, której odpowiednik w skali Celsjusza wynosi 58,75 stopni, musiałaby być mierzona w słońcu. Temperatura sierpnia wynosząca 27 stopni Celsjusza wydaje się, co prawda, znacznie zaniżona w zestawieniu $z$ maksymalnymi temperaturami egipskiego lata, ale jest zgodna $\mathrm{z}$ przeciętną uwzględniającą temperatury dnia i nocy. Oczywiście, temperatura 27 stopni Réaumura, czyli 33,75 stopni Celsjusza, wygląda prawdopodobniej, lecz i tak nie jest to maximum sierpniowe, bo siega ono co najmniej 45 stopni Celsjusza w cieniu. Skala Celsjusza była znana w Królestwie Polskim, chociaż dopiero w XX w. całkowicie wyparła skalę Réaumura.

Na s. 596 edycji Faraona cytatowi w kalendarium dotyczącym Edwarda Okunia, umieszczonym po eseju Małgorzaty Biernackiej: „Vivitur ingenio caetera mortis erunt” (poprawnie: cetera), towarzyszy przekład Kraushara: „Żyjmy duchem, albowiem wszystko inne należy do śmierci”; może trochę dokładniej byłoby: „Żyje się życiem umysłowym, reszta padnie łupem śmierci".

Pogląd, że „Obraz niewolników w powieści odwzorowuje system znany z Cesarstwa Rzymskiego" (przypis 8 na s. 25), nie jest całkiem trafny, ponieważ kulminacja masowego wykorzystania niewolnej siły roboczej w Italii i prowincjach przypada raczej na czasy późnej republiki rzymskiej niż cesarstwa. To wtedy wybuchło słynne powstanie niewolników pod wodzą Spartakusa.

Także niektóre inne komentarze wydawcy (np. w przypisie 176 na s. 134) są dyskusyjne. Kiedy Prus pisze o przyszłym „stanowisku” Herhora, nie ma raczej na myśli godności arcykapłana Amona, już piastowanej przez tego dostojnika, ale urzędy „których było pełno w świątyniach i przy dworze” (s. 134).

„Pułk Jeb” (s. 329) to według Niwińskiego nazwa pochodzaca od wyrazu „ib [serce]" (przypis 356), tymczasem wydaje się, że jest to nazwa terytorialna wywodząca się z egipskiego określenia wyspy Elefantyny, zwanej pierwotnie $A b u$, a później Jeb(u). Oczywiście, za użyciem tej nazwy kryje się dyskretny uśmiech Prusa-humorysty.

„Mnemonie” miałyby być pomyłką - zamiast: „memnonie”; jest to dość skomplikowana kwestia, ale objaśnienie w wydaniu Niwińskiego w przypisie 400 na s. 388 wydaje mi się błędne; użyty przez Prusa wyraz „mnemonie” pochodzi najwyraźniej od greckiego „mnemeion [grobowiec]”, zapewne mylnie utożsamionego $\mathrm{z}$ formą „mnemoneion”. Nawiasem mówiąc, Prus miał z greki zaledwie trójkę; możemy mu to drobne potknięcie wybaczyć.

W przypisie 556 na s. 496 wydawca wyjaśnia słusznie, że zjawisko dźwięków wydobywających się $\mathrm{z}$ jednego $\mathrm{z}$ posagów Amenhotepa III w Tebach Zachodnich (tzw. kolosów Memnona) jest poświadczone dopiero w okresie rzymskim. Nie ma jednak racji pisząc, że dźwięki te wydawał posag „przewrócony”. W istocie posag rozpadł się (zapewne w wyniku trzęsienia ziemi) i jego górna część leżała obok dolnej, z której od tego czasu wydobywały się o wschodzie słońca tajemnicze dźwięki.

17 Garść spostrzeżeń i uwag do komentarzy Niwińskiego zawarłem w przywoływanym już artykule Spojrzenie na starożytny Egipt z XIX-wiecznej Warszawy, który niebawem ukaże się drukiem. 
Mówi o tym rzymski poeta Juwenalis, pisząc w Satyrze XV o „połówce Memnona”: "dimidio magicae resonant ubi Memnone chordae" 18 . Zjawisko akustyczne zanikło, gdy posag naprawiono, jednak nie na przełomie w. II i III, lecz około 215 roku $^{19}$.

Niwiński jest pewien, że w Egipcie nie używano „map sztabowych”, ale przecież $\mathrm{w}$ ogóle istniały wówczas mapy i plany rysowane na papirusie.

Chyba przesadny jest również wyrażony przez wydawcę powściagliwy pogląd na stosowanie w dawnym Egipcie trucizn (s. 376, przypis 393). To, że nie sa one poświadczone w zachowanych tekstach, wydaje się zrozumiałe - zapewne unikano spisywania takich groźnych instrukcji.

Osobne zagadnienie stanowi język Prusa i jego „poprawianie” przez Niwińskiego. Uważny czytelnik starszych edycji Faraona łatwo dostrzeże na kartach wydania z 2014 r. liczne ingerencje w język pisarza. Na s. 323 Niwiński poprawia „latać po powietrzu” 20 na „latać w powietrzu”. Forma „osieł”21 została (na s. 37) zastąpiona przez dzisiejszą formę „osioł”, stanowiącą dyskretny, ale jednak rusycyzm. „Generał” zastapił forme ,jenerał”. Podobnie jest $\mathrm{z}$,jeografia”" i milami ,jeograficznymi” (s. 512, przypis 589). $Z$ punktu widzenia najprostszych zasad sztuki edytorskiej ingerencje tego typu sa niedopuszczalne.

Najbardziej kontrowersyjna kwestia zajmująca komentatorów Faraona to pytanie: czy Prusowi rzeczywiście chodziło o przedstawienie niezmiernie odległego w czasie epizodu $z$ dziejów państwa faraonów? Niektórzy wątpią o tym i sugerują, że jest to powieść „Z kluczem”. Nie zamierzam tu analizować literatury fachowej poświęconej Faraonowi. Wymagałoby to osobnej publikacji książkowej. Postaram sie jednak odpowiedzieć na sformułowane tu pytanie, chociaż odpowiedź będzie miała jedynie postać garści luźnych impresji.

Prus był pisarzem wybitnym, nawet genialnym, ale jego poglądy na dzieje zarówno egipskie, jak polskie nie miały i nie mają waloru nieomylności. Autor Faraona uważał, że „Przed trzema, czterema, a nawet pięcioma tysiącami lat [...] w środkowej Europie odziani w surowe skóry barbarzyńcy kryli się po jaskiniach [...]" (s. 23). To nieprawda, ale jako nieporozumienie historyczne nie jest to wcale bardziej rażące niż wizja Polski wczesnopiastowskiej czy przedpiastowskiej u Józefa Ignacego Kraszewskiego.

Zalecana kiedyś do czytania w szkole (nie bez powodów, związanych z powojenną wykładnią historii Polski) napisana przez Prusa krytyczna recenzja Ogniem i mieczem ${ }^{22}$ przy dążeniu do racjonalizmu w niemałym stopniu upraszczała złożone zjawiska historyczne. Także pretensje dzisiejszej komentatorki Faraona do Sienkie-

Wers ten w przekładzie J. S ę kow s kiego (w: Trzej satyrycy rzymscy. Horacy - Persjusz - Juwenalis. Wstęp i komentarz w oprac. L. W i n n i c zu k. Warszawa 1958, s. 213) brzmi: „Gdzie nuci Memnon, dzierżąc magiczną kitarę", co rażąco odbiega od oryginału. Cytowany wers należałoby przetłumaczyć tak: „gdzie w połówce Memnona brzmią magiczne struny”.

Zob. A. Łukaszewicz, Aegyptiaca Antoniniana. Działalność Karakalli w Egipcie (215-216). Warszawa 1993, s. 163-166.

20 Tak w wydaniu Faraona z r. 1952 (s. 394).

21 Ibidem, s. 20.

22 B. Pru s, „Ogniem i mieczem”. Powieść z lat dawnych Henryka Sienkiewicza. W: Pisma. T. 29: Studia literackie, artystyczne i polemiki. Red. Z. Szw e y k ow s ki. Warszawa 1950. 
wicza o to, że „W Ogniem i mieczem zwykły chłop nie wpływa na losy państwa [...]”23, są niesłuszne. Czy rzeczywiście pojedynczy chłop miał wpływ na losy państwa? Nie wiem, czy naprawdę Prus, przynajmniej w Faraonie, przypisywał tzw. prostym ludziom „wartość najwyższą w społeczeństwie”, jak to sugeruje Roksana Blech ${ }^{24}$. Współczucie Prusa dla niedoli ludu bierze się z oczywistego stwierdzenia, że prości ludzie są istotami czującymi, a przez to zasługującymi na życzliwość i litość.

Andrzej Niwiński uznaje Faraona za metaforę odnoszącą się do dziejów Polski. Jego koncepcja, oparta na poglądach, wedle których to powieść o Polsce w przebraniu egipskim (cytaty na s. 641), jest, moim zdaniem, nietrafna. Przede wszystkim bowiem Faraon jest powieścią o państwie, a w czasach Prusa nie istniało państwo polskie. Gdyby zaś Faraon miał opowiadać o upadku Polski przedrozbiorowej, analogia egipska byłaby mylna, gdyż Egipt nie upadł wcale $\mathrm{z}$ końcem XX dynastii i Prus to trwanie państwa egipskiego podkreśla w epilogu powieści.

Niwiński przytacza niektóre poglądy Marii Dąbrowskiej i Franciszka Ziejki na domniemane intencje Prusa. Jednak tezę Ziejki, że Faraon rzeczywiście opowiada o Egipcie za XX dynastii, określa Niwiński expressis verbis jako „nieprawdziwą"25. Szuka zatem „drugiego dna” powieści. Pomysł dotyczacy „400 lat” - mylnie podanego przez Prusa odstępu w czasie między dynastią XIX a schyłkiem dynastii XX - służy Niwińskiemu za punkt wyjścia do rozumowania na temat rzekomego zamiaru pisarza nawiązania do dziejów Polski. 400 lat odpowiada bowiem interwałowi czasowemu między XV wiekiem, okresem potęgi państwa polskiego, a wiekiem XIX, czasem upadku (mówi o tym np. przypis 279 na s. 214). Owe 400 lat występuje jednak i w innym miejscu powieści jako odstęp w czasie od „rewolucji” amarneńskiej faraona Amenhotepa IV do epoki powieściowego Ramzesa XIII (s. 463). W rzeczywistości odstęp ten wynosił około 280 lat. Natomiast XIX dynastia zaczęła się w kilkadziesiąt lat po herezji amarneńskiej, a zatem około 220 lat przed schyłkiem panowania ostatniego władcy XX dynastii, Ramzesa XI. W obu przypadkach wydaje się, że chodzi po prostu o mylne, czy może zanadto przybliżone, wyliczenie Prusa, nie zaś o jakąs wymyślną aluzję do odstępu między okresem jagiellońskiej potęgi a upadkiem Polski. W tym ostatnim przypadku zresztą czas można też liczyć różnie, bo zarówno jako około 400 lat (np. 1386-1795), jak i 300 lat (np. 1493-1793), zależnie od dat, które się wybierze.

W innym miejscu powieści Prus ustami księcia Ramzesa ocenia czas od wyjścia Żydów z Egiptu na „trzy wieki” (s. 70). Według rozpowszechnionego do dziś (skądinąd, moim zdaniem, mylnego) poglądu, żydowski Exodus należy wiązać ze schyłkiem XIX dynastii, czyli z okresem około 1210 r. p.n.e. Do czasów, w których rozgrywa się akcja Faraona, upłynęło zatem od tego wydarzenia około półtora wieku, pisarz podaje zaś trzy wieki. Oznacza to, że jego ocena chronologii Egiptu nie była ścisła. W XIV w. p.n.e. Exodus jest natomiast mało prawdopodobny. Rzeczywiste Wyjście Żydów z Egiptu należy, według piszącego te słowa, do XVI w. p.n.e. i mogło mieć miejsce około 1525 roku p.n.e. ${ }^{26}$ 
Jeśli koniec XIX dynastii był rzekomo odległy od czasu akcji powieści o 300 lat, to początek z pewnością o 400, bo dynastia ta panowała przez blisko 100 lat. Oto zapewne źródło owych 400 lat od XIX dynastii do panowania Ramzesa XIII.

Niwiński jest zdania, czemu dał wyraz w swoim szkicu komentującym Faraona ${ }^{27}$, a także w prelekcji wygłoszonej 1 X 2014, że w chwili publikowania tej powieści Prus jako zwolennik ugodowego podejścia do caratu (udział w audiencji u cara Mikołaja II w czasie jego wizyty w Warszawie 31 VIII - 3 IX 1897) utracił prestiż w oczach części społeczeństwa. Istotnie, Prus w okresie pisania Faraona i później odszedł był już od poglądów, które go jako młodzieńca zaprowadziły do powstania 1863 roku. Odniesiona rana, wstrząs psychiczny i dramatyczne perturbacje związane $z$ udziałem w powstaniu, jak też refleksja nad jego przebiegiem i klęską musiały wpłynąc na postawę pisarza. Skądinąd jednak to Prus, a nie Sienkiewicz, gdyby dożył niepodległej Polski, co teoretycznie nie było niemożliwe, otrzymałby zapewne Krzyż Srebrny Orderu Virtuti Militari (rana odniesiona w boju z nieprzyjacielem!), a na pewno Krzyż Niepodległości z Mieczami. Mógłby też paradować $\mathrm{w}$ granatowo-amarantowym mundurze weterana.

Czarno-biały obraz polskiego społeczeństwa pod zaborem, podzielonego dychotomicznie na patriotów i ugodowców, zanadto upraszczałby prawdę historyczną. Prus przez swoje umiarkowane poglądy wcale nie utracił w Polsce nawet części społecznego prestiżu, choć bywał z różnych powodów atakowany. Ostatecznie został uznany za „nauczyciela narodu” (napis na tablicy w warszawskim kościele św. Krzyża), a na jego grobie wyryto powszechnie znane słowa. Pogrzeb Prusa w maju 1912 miał charakter wielkiej narodowej manifestacji, która wryła się w pamięć warszawiaków tak dalece, że mój ojciec, który był wtedy małym dzieckiem, zapamiętał owo wydarzenie! Skądinąd na tym pogrzebie nie zabrakło awantur, jednak nie były to przejawy niechęci do zmarłego, ale wręcz przeciwnie - spory o zaszczyt niesienia jego trumny, w których doszło do utarczek między studentami Politechniki a zwolennikami bojkotu rzadowych instytucji edukacyjnych ${ }^{28}$.

Dziś Prus ma w Warszawie pomnik. Zapewne ze względu na dręcząca pisarza agorafobię, brązowy Prus stanął na niskim cokole, $z$ dala od ulicy, jako dyskretny obserwator wydarzeń. Dlaczego jednak przedstawiony jest na tym pomniku jako zmęczony starzec? Czy ów pełen pasji pisarz tak właśnie chciałby widzieć samego siebie? Podobny los spotkał zresztą także jego rywala, Sienkiewicza, który na pomniku w Łazienkach jest umierającym starcem $z$ odchodzacej epoki, a karty jego dzieł trawi ogień. Czyżby chodziło o alegorię klęski i zgonu przedrozbiorowej Polski?

Co jednak skłoniło Prusa akurat w r. 1894 do zajęcia się starożytnym Egiptem i skonstruowania tragedii prozą z filozoficznym przesłaniem? Atrakcyjność tematu była w owej epoce oczywista. Ze świata docierały echa powszechnego zafascynowania dawną kulturą tego kraju. Muzea europejskie rozbudowywały kolekcje staro-

27 Niwińs ki, Literacka wyprawa Bolesława Prusa do starożytnego Egiptu [...], s. 642, przypis 65.

28 Zob. M. Rolf, Rządy imperialne w Kraju Nadwiślańskim. Królestwo Polskie i cesarstwo rosyjskie (1864-1915). Przeł. W. Wł o s k o w i c z. Warszawa 2016, s. 269-270. 
żytności egipskich. W roku 1867 wystawa paryska prezentowała m.in. pawilon egipski w postaci kopii słynnej świątyni w Edfu. W roku 1869 w obecności francuskiej cesarzowej Eugenii otwarto Kanał Sueski. Wicekról (chedyw) Egiptu, Ismail, znany frankofil, oznajmił publicznie, że Egipt nie jest już częścią Afryki, lecz należy do Europy ${ }^{29}$.

Prus już w Lalce zdradził się z zainteresowaniem starożytnym Egiptem, umieszczając w tej znakomitej powieści (skądinąd marginesową i milczącą) postać uczonego egiptologa. W owym czasie prawdziwych egiptologów w Polsce jeszcze nie było, jeśli pominąć postacie takie, jak Józef Sękowski (1800-1858), rówieśnik Mickiewicza, albo współczesny Prusowi kolekcjoner i archeolog-amator Michał hr. Tyszkiewicz (1828-1897), który prowadził pierwsze regularne polskie wykopaliska w Egipcie. Ciekawy i literacko wartościowy opis Egiptu pozostawił Władysław Wężyk (1816-1848). Ignacy Żagiell (1826-1891) opublikował w 1880 r. wykorzystaną przez Prusa Historię starożytnego Egiptu. Właściwie dopiero w czasach bliskich powstania Faraona pojawiają się u nas coraz częściej zarówno popularyzatorzy wiedzy o dawnym Egipcie, jak i samodzielni badacze. Pod koniec życia pisarza można już mówić o polskich egiptologach, archeologach Egiptu i papirologach, m.in. o niebywale uzdolnionym i przedwcześnie zmarłym Tadeuszu Smoleńskim (1884-1909), prowadzącym wykopaliska w Szaruna i Gamhud, o papirologach Stefanie Waszyńskim (zm. 1908) i Stanisławie Witkowskim (1866-1950), o działającym także w Egipcie archeologu Piotrze Bieńkowskim (1865-1925), kopiącym w El-Kubanije, o Karolu Hadaczku (1873-1914), działajaccym w Gizie, czy o historyku Tadeuszu Wałku-Czerneckim (1889-1949), późniejszym inicjatorze wykopalisk Uniwersytetu Warszawskiego w Egipcie (inicjatywę tę zrealizował Kazimierz Michałowski). W czasach poprzedzajacych powstanie Faraona tom encyklopedii Orgelbranda z 1891 r. informował o starożytnym Egipcie. O kraju faraonów mówiła także niezwykle popularna Historia starożytna pióra Tadeusza Korzona (1839-1918).

Z wcześniejszego niż Faraon okresu twórczości Prusa można jeszcze wspomnieć opowiadanie $Z$ legend dawnego Egiptu (z końca 1887 roku). W nim z kolei, bezzasadnie jak mniemam, dopatrzono się aluzji do ówczesnych układów personalnych w Cesarstwie Niemieckim ${ }^{30}$. Oczywiście, w wielu miejscach Faraona znajdują się ponadczasowe aluzje i żarty Prusa, które można także uznać za nawiązanie do epoki pisarza. Sa to jednak tylko przejawy realizmu i poczucia humoru. Tak jest z historyjką o swawolnym żołnierzu bezkarnie uwodzącym żonę chłopa (s. 95) albo $z$ „dobra radą” fenickiego szynkarza, który sugeruje Beroesowi (udającemu Phuta, przybysza z Harranu), by nie wdawał się z egipskim sądem (s. 148), i proponuje mu spółkę w handlu kobietami. Dziewczyna, która mówi, że jeszcze nie narwała sałaty na obiad, to nie tyle obrazek przeniesiony z Polski, ile element realizmu historycznego, gdyż w starożytnym Egipcie też jadano sałatę. Opis przebiegu zaćmienia słońca odzwierciedla własne obserwacje Prusa, który widział takie zjawisko. Rozmowy Fenicjan, np. w zajeździe Assarhadona, próba uwiedzenia Sary przez

30 Zob. Zinkow, op. cit., s. 666. Zob. też L. Zin k ow, Pharaonic Disguise. Egyptianizing Staffage of Modern Politics. „Studies in Ancient Art and Civilization” 16, 2012, s. 269-276. 
Dagona, rozmaite inne dialogi związane z życiem codziennym to znakomite teksty, dające się zastosować do różnych czasów i kultur. Dialogi Fenicjan w Faraonie, przynajmniej w pewnych partiach tych tekstów, wystylizował Prus według wzorów znanych ówcześnie $z$ codziennego życia miejskiego, w którym znaczną rolę odgrywała ludność żydowska. Teksty te brzmią niekiedy humorystycznie, chociaż nie wiem, czy można do nich zastosować określenie „szmonces” (s. 193, przypis 255), które przecież odnosi się nie tyle do parodiowania charakterystycznego sposobu mówienia, ile do żydowskiego dowcipu i opartej na nim kabaretowej groteski. Nie można $z$ tego zabiegu stylistycznego wysnuwać wniosku, że Faraon w istocie porusza problemy polskie.

Także motyw niechęci do Żydów, jaką rzekomo przejawiali Egipcjanie, nie jest odbiciem nowożytnego antysemityzmu, ale wynika raczej stąd, że autor na podstawie przekazu biblijnego uznawał Egipcjan za antagonistów Żydów i traktując ten starotestamentowy motyw jako fakt historyczny, wprowadził go do powieści. Dramatyczna historia „uczynienia Żydem” (czyli obrzezania) małego synka księcia Ramzesa opiera się na nieporozumieniu. Prus mógł nie wiedzieć, że w czasach, o których pisze, także Egipcjanie poddawani byli obrzezaniu. Tragedia Żydówki Sary, szlachetnej i, być może, jedynej nieskazitelnej pierwszoplanowej postaci $\mathrm{Fa}$ raona, przeczy niesłusznym posadzeniom Prusa o poglądy antysemickie. Prus w Lalce wyłożył swój pogląd na różne aspekty społeczne współżycia chrześcijan i Żydów i nie potrzebował do tego Faraona. Kto wie, czy jakiegoś wpływu na wprowadzenie wątku żydowskiego do powieści nie miała znajomość treści opery Jacques'a Halévy'ego Żydówka, dzisiaj rzadko wystawianej, ale popularnej w XIX wieku. Premiera warszawska tej opery odbyła się w 1857 roku. Prus mógł też znać tekst Eugène’a Scribe’a, który posłużył jako podstawa libretta. Główna bohaterka tego dramatu, Rachela, porzucona przez kochanka-chrześcijanina z powodu odmiennego wyznania, zostaje przez chrześcijańskie władze oskarżona o przestępstwo religijne $\mathrm{i}$ wobec trwania przy swej wierze skazana razem $\mathrm{z}$ ojcem na śmierć w męczarniach. Opowieść Prusa o Sarze jest oczywiście nieco inna, ale ona także opiera się na dramacie wynikającym $z$ nietolerancji.

Wydarzenia rozgrywające się w Polsce nie zawierały żadnego istotnego impulsu do powstania Faraona. Natomiast w imperium rosyjskim akurat w r. 1894 nastapiła nieoczekiwana zmiana na tronie, która po przedwczesnej śmierci Aleksandra III (1 XI 1894) wyniosła młodego carewicza Mikołaja na wyżyny władzy absolutnej. Można by przypuszczać, że właśnie to wydarzenie stanowiło impuls sprzyjający powstaniu Faraona, osnutego wokół sprawy następstwa tronu i dylematów absolutnej władzy. Jednakże praca nad pomysłem Faraona zaczęła się wcześniej niż w chwili śmierci niestarego jeszcze cesarza Wszechrosji, a mianowicie w maju 1894. Niemniej w trakcie pisania i kształtowania zasadniczych wątków powieści zmiana na tronie cesarstwa musiała odegrać pewną rolę. Ta inspiracja nie mogła przejść niezauważona i rzeczywiście pojawiły się teorie zakładające, że Ramzes XIII to w przybliżeniu Mikołaj II, a Herhor to oberprokurator Świętego Synodu, Konstantin Piotrowicz Pobiedonoscew ${ }^{31}$. Jednak bezsilny i schorowany stary faraon Ram- 
zes XII, pozbawiony realnej władzy przez wszechwładnych kapłanów, w niczym nie przypomina energicznego i bezwzględnego Aleksandra III.

Nawiasem mówiąc, wydaje się, że Prus nie mógł się zdecydować, czy sugerować czytelnikowi, że Ramzes XIII był w rzeczywistości synem Herhora. Pisarz zatrzymał się w połowie, ograniczając się do jednej czy dwóch dwuznacznych aluzji. Trudno jednak wątpić o tym, że Herhor był kochankiem królowej, córki arcykapłana. Ponadto sam Herhor mówi do siebie, że to on uczynił Ramzesa faraonem i że młodzieniec „dlatego tylko został faraonem, że jest wnukiem arcykapłana” (s. 421). Ta informacja została zresztą implicite podana przez Prusa na początku powieści (s. 30).

Komentarze Niwińskiego rozsiane po przypisach do dzieła Prusa odzwierciedlają pomysł edytora na „klucz” do Faraona. Np. na stronicy 66, w przypisie 99, Niwiński stwierdza:

Podobnie, jak rzekome zagrożenie ze strony obcego mocarstwa, tak samo motyw niedawno przebytych wojen był Autorowi potrzebny do przedstawienia aktualnej sytuacji Polski w końcu XIX wieku. W prawdziwej historii starożytnego Egiptu wiek XI p.n.e. był okresem niezagrożonego pokoju, a ostatnia wojna, jaką stoczył, miała miejsce za Ramzesa III, sto lat przed czasem, w którym została umieszczona akcja powieści.

Istotnie, zagrożenie Egiptu przez Asyrię pod koniec XX dynastii to fikcja literacka. Jednak pod koniec XIX w. także Polsce nie zagrażało żadne obce mocarstwo, zwłaszcza że państwo polskie nie istniało. Można mówić co najwyżej o zarysowującym się konflikcie niemiecko-rosyjskim i o sojuszu Rosji z Francją. Gdyby obstawać przy koncepcji proponowanej przez Niwińskiego, to w polskiej rzeczywistości r. 1895 rolę groźnej Asyrii grałyby chyba raczej ekspansywne Niemcy Wilhelma II. Może taka koncepcja nawet i przeszła przez myśl Prusowi, jednak skądinąd na tematy „niemieckie” autor Placówki wypowiadał się dość otwarcie i nie potrzebował do tego starożytnego przebrania.

Jaki sens miałyby mozolne usiłowania Prusa, by zdobyć gruntowną (w jego przekonaniu) wiedzę o dawnym Egipcie, gdyby ów Egipt stanowił tylko kamuflaż dla istotnego przekazu dotyczącego Polski? Egipt był mimo wszystko potężnym państwem, mającym własnego króla. O Polsce sensu largo można było w $1895 \mathrm{r}$. mówić co najwyżej jako o „ziemiach dawnej Polski”. Tadeusz „Boy” Żeleński pisał żartobliwie, zaczynając od słów: „Nie mamy w Polsce monarchy [...]”.

„Motyw niedawno przebytych wojen” może i dałoby się odnieść do Polski, ale nie bez poważnych zastrzeżeń. Ostatnia regularna wojna na terytorium Królestwa Kongresowego toczyła się w 1831 roku. Co się tyczy Egiptu za XX dynastii, to wojna zewnętrzna nie była wcale zjawiskiem aż tak odległym w czasie. Nowsze badania wskazują wyraźnie, że wycofanie się Egiptu z zależnych obszarów Bliskiego Wschodu już po Ramzesie III (1184-1153 p.n.e.), zwłaszcza za Ramzesa VI (1143-1136 p.n.e.), nie przebiegało pokojowo, lecz było wynikiem działań wojennych. Za ostatnich Ramessydów nie miały wprawdzie miejsca wojny zewnętrzne, ale Egiptem wstrząsnęła wojna domowa, o czym akurat Andrzej Niwiński, znawca epoki (co

Literatura polska okresu realizmu i naturalizmu. T. 2. Red. J. Ku l c zy c k a - S a lo ni [i in.]. Warszawa 1966. 
słusznie podkreśla Leszek Zinkow w szkicu zamieszczonym w edycji), autor publikacji o tych wydarzeniach, bardzo dobrze wie ${ }^{32}$.

Niwiński pisze, że za „Ramzesów IV i V inflacja nadal rosła”33. „Inflacja” to wprawdzie termin odnoszący się do gospodarki pieniężnej, której ówczesny Egipt nie znał, rozumiemy jednak, iż chodzi o drożyznę. Głód, a przede wszystkim pustoszenie kraju przez wojska walczących ze sobą stron wewnętrznego konfliktu były istotnymi czynnikami schyłku Nowego Państwa. Niwiński wszakże w przypisie 290 na s. 221 niejako zaprzecza temu pisząc, że w Egipcie „w ciagu XIII-XI w. p.n.e. poziom życia w zasadzie się nie zmienił”, a obraz upadku w „kazaniu” Pentuera „stanowi aluzję do zmian stosunków społecznych zachodzących w Polsce pomiędzy XV a XIX w." Trzeba tu zauważyć, że faktyczne zubożenie ludności w dawnej Polsce było nie tyle rezultatem „zmian stosunków społecznych”, ile skutkiem wyjątkowo gwałtownych walk wewnętrznych i najazdów. Od roku 1648 Rzeczpospolita była pustoszona przez rebelię Kozaków i wynikłe z niej powstanie ludowe oraz wojnę, a także przez Tatarów, Moskali, Szwedów, Niemców, Węgrów i Turków, miejscami zamieniając się $w$ ruinę i pustynię, nieporównywalną $z$ dawnym rozkwitem. Niebywałym wysiłkiem, mimo wewnętrznych kłótni i konfliktów, udało się w XVII w. stłumić powstanie, zatrzymać pochód wojsk moskiewskich, wypędzić Szwedów i ich sprzymierzeńców, a wreszcie manu militari doprowadzić do rozejmu i ustalenia na przeszło 100 lat tylko umiarkowanie cofniętej granicy na wschodzie. Spustoszenia były ogromne, poziom gospodarki, kultury i życia codziennego przetrzebionej ludności spadł drastycznie. Straty w procentach ogółu ludności były większe niż w czasie drugiej wojny światowej. Potem zwaliły się na Polskę następne wojny. Ale nawet ze starcia $z$ potężnym imperium tureckim Polska wyszła w miarę obronną ręką. Aż do końca panowania Jana III polski system ustrojowy mimo swych niewątpliwych wad zdawał dziejowy egzamin.

W Egipcie nawet w przybliżeniu nie było podobnych perturbacji, aczkolwiek zaburzeń nie brakowało. Trzeba (zgadzając się tu z Niwińskim) stwierdzić, że - pomijając okresy nieurodzaju - zmiany w poziomie materialnym życia przeciętnego chłopa egipskiego nie były z pewnością aż tak drastyczne, jak to wynikałoby z powieści Prusa. Obserwacje Prusa na temat wojny i pokoju można jednak uznać za wyobrażenia pisarza odnoszące się do dziejów Egiptu. Wiadomości czerpane przez autora Faraona z XIX-wiecznej literatury popularyzującej wiedzę o Egipcie, choć może niezbyt precyzyjne, wystarczały do wyobrażenia sobie schyłku XX dynastii jako czasów upadku, nędzy szerokich rzesz ludności i zaburzeń społecznych.

Nie dość trafna $z$ punktu widzenia dzisiejszej nauki charakterystyka sytuacji Egiptu w Faraonie nie stanowi dowodu na to, że w istocie pisarzowi chodziło o Polskę, a nie o Egipt.

W Egipcie koniec XIX dynastii przyniósł poważne zaburzenia polityczne. Na początku dynastii XX miały miejsce zwycięskie wojny obronne przed najazdami, potem dramatyczna próba zamachu stanu (w wyniku spisku pałacowego zamordo- 
wano Ramzesa III) i spory o sukcesję, natomiast pod koniec XX dynastii z pewnościa załamał się system państwowej dystrybucji dóbr oraz nastąpił okres chaosu i grabieży. Szukanie analogii między tymi dziejami (w wersji przyjętej przez Prusa) a sytuacją Polski z czasów pisarza byłoby błądzeniem po manowcach. Rzekome zaś podobieństwo Egiptu Prusa do Polski przedrozbiorowej jest powierzchowne i złudne.

Niwiński za istotny element swego rozumowania o „polskim” przesłaniu Faraona uważa fakt, że Prus podobno wycofał pierwotne zakończenie powieści, rzekomo w wyniku nacisku i ugody $z$ rosyjska cenzurą ${ }^{34}$. To jednak tylko hipoteza. Czy to zakończenie, już od dość dawna umieszczane w wydaniach powieści, rzeczywiście zawierało jakieś elementy niecenzuralne z punktu widzenia rosyjskiego okupanta? Trudno się czegoś podobnego dopatrzyć. Jest to filozoficzna refleksja nad historia i życiem ludzkim, wyraz niejako stoickiego podejścia do dramatów losu i egzystencji, a zarazem uspokojenie czytelnika po burzy emocjonalnej. Tragiczna śmierć młodego faraona musiała wzbudzić u wrażliwego odbiorcy tekstu głęboki żal nad niezasłużoną klęską szlachetnej jednostki. Epilog wylewa oliwę na te wzburzone fale, tłumaczy prymat przystosowania nad buntem i sprzeciwem, jest jak refleksyjne adagio po jakimś presto, a nawet furioso. Rezygnacja z zakończenia mogła być po prostu wynikiem zmiany poglądu autora, który przypuszczalnie zdecydował się na zamknięcie dramatu akcentem tragicznym, jakby ostatnim akordem wielkiej bohaterskiej symfonii.

Na czyjeś pytanie, czy Faraon jest powieścią o Polsce w przebraniu egipskim, Prus miał podobno zareagować odpowiedzią: „Jak pan wie, to czego się pan pyta?" 35 To jednak nie znaczyło, że naprawdę "pan wie”. Odwrotnie, niż to zakłada Niwiński, ta wypowiedź Prusa brzmi wyraźnie jak zdystansowanie się od głupiego pytania. To bardzo warszawski, lekko ironiczny zwrot. Nie można $z$ niego wnioskować, że zadający pytanie rzeczywiście dobrze odczytał intencje Prusa, a pisarz to potwierdził.

Podobnie wątpliwe jest twierdzenie, że przymiotnik „tysiącoletni” odnosi się w rzeczywistości do „tysiącletniej” Polski, a nie do Egiptu ${ }^{36}$. Po pierwsze „tysiącoletni" nie wskazuje na jeden tysiąc lat, ale równie dobrze na kilka tysięcy lat dziejów. Po wtóre, w r. 1895 przymiotnik „tysiącletni” i pojęcie „tysiąclecia” nie miały w Polsce takiego obiegowego znaczenia, jakiego nabrały w drugiej połowie XX w., przy okazji obchodów nazwanych millenijnymi.

Wygląda na to, że jedyny pewny „wątek polski” w Faraonie to wzmianka o krajach, w których „rodzi się bursztyn” oraz o jasnowłosej niewolnicy porwanej gdzieś daleko przez ludzi Hirama, która zmarła z tęsknoty za ojczyzną (s. 300). O ile bursztyn bałtycki był w czasach faraonów prawie nieznany na Bliskim Wschodzie, o tyle nie należy a priori odrzucać możliwości docierania aż nad Bałtyk żeglarzy z Morza Śródziemnego. Poszlaki, które na to wskazują, bywają dzisiaj lekceważone, ale przyszłe badania niewątpliwie dostarczą dalszych danych i wyjaśnią tę niebywale interesującą kwestię.

Zob. E. Warzenica-Zalew ska, Dwa zakończenia „Faraona” a sens ideowy powieści. „Pamiętnik Literacki" 1985, z. 2. 
Nie jestem przekonany do tezy Niwińskiego, że w zakończeniu Faraona pojawia się „wątek "ku pokrzepieniu serc" "37 - nawiasem mówiąc, cytat w tej rozpowszechnionej postaci (tak go przytaczają m.in. Niwiński i Blech) jest błędny: Sienkiewicz pisał „dla pokrzepienia serc”. Roksana Blech twierdzi skądinąd, że zastrzeżenia Prusa wobec Ogniem i mieczem budziło właśnie „przesłanie powieści - owo "ku pokrzepieniu serc" "38. Lecz w Ogniem i mieczem jeszcze tej sentencji nie ma, gdyż Sienkiewicz umieścił ją dopiero na końcu Pana Wołodyjowskiego. Zresztą Ogniem i mieczem wcale nie kończy się optymistycznie - to tylko chwilowy i umiarkowany happy end na tle klęsk, konfliktów i ruiny dawnego (pozornie) harmonijnego bytu i (względnej) zgody narodów w Rzeczypospolitej sprzed roku 1648. Jednakże sens dzieła Sienkiewicza tkwi nie w jakimś budującym zakończeniu, ale w porywającej malowniczości nakreślonych przez pisarza obrazów. Nie daja one czytelnikowi satysfakcji, lecz budzą nostalgię. Nie tak znów wiele różni Ogniem i mieczem od Faraona!

Prus niewątpliwie rozważa w Faraonie nie tyle sprawe polska, ile sprzeczności będące udziałem władzy despotycznej. Władca, bardziej jeszcze absolutny od rosyjskiego cara, w dodatku otoczony boską czcią, pomimo osobistej odwagi i talentu okazuje się bezbronny wobec zakulisowych struktur i „układów”. Jest po prostu spętany i ginie, gdy chce się wyrwać spod kurateli. Ramzes XIII umiera zamordowany przez zamachowca, będącego bezwolnym narzędziem w ręku potężnych wrogów faraona.

W czasach Prusa tragiczny los spotykał wielu władców. Trony padały od Francji i Portugalii po Meksyk, Brazylię, Koreę i Chiny, a zmierzch monarchii - jak się miało niebawem okazać - wcale nie oznaczał postępu i poprawy bytu narodów.

Pogląd pisarza na los króla znalazł wyraz w Faraonie: według pieśni śpiewanej na Nilu przez Sarę król nosi zbroję pod purpurą i łowi uchem szmer kotary (s. 118) - nawet jeśli to wpływ wydarzeń 1881 i 1887 r., należy uznać, że chodzi o refleksje ogólniejsze niż tylko wynikające ze spraw polskich z czasów autora.

$Z$ całą pewnością Prus piętnując pychę i arogancję klas posiadających i współczując uciśnionemu ludowi nawiązuje także do sytuacji sobie współczesnej. Jednak wrogiem człowieka okazuje się nie tylko ciemiężyciel z klasy posiadaczy, ale inny „prosty człowiek”, którego podły charakter i żądza zysku popychają do czynów haniebnych i zbrodniczych. Ramzesa XIII zabija jakiś marny grecki śpiewak, który przedtem zamordował jego dziecko. Tutmozis pada rozcięty toporem przez grubiańskiego, chytrego i wygadanego prostaka, sprzedajnego karierowicza Eunanę. Wspólnikami Eunany sa inni zdrajcy spośród zwykłych żołnierzy. Parobków na folwarku Sary bija ich krewni. Chytra Tafet, ciotka Sary, okrada folwark na rzecz rodziny i znajomych. Biciem chłopów i brutalnym poborem danin zajmuje się jakiś obskurny, gadatliwy i przemądrzały pisarz. Ubogiego mędrca, kapłana Menesa, żebrzącego po wsiach, przepędzają prości wieśniacy, itd. Można się w niektórych opisach konfliktów społecznych w Faraonie dopatrzyć aluzji do problemów współczesnych Prusowi. Jednak nie wystarczy to do stwierdzenia, że powieściowy Egipt to Polska w przebraniu. 
Związki Faraona z rzeczywistością współczesną pisarzowi są niewątpliwe. Aluzji do okresu, w którym Prus żył i tworzył, nie brakuje. Byłoby dziwne, gdyby ich zabrakło w dziele tak wytrawnego dziennikarza. Jednak Faraon nie jest powieścią ani o Polsce, ani o Rosji, ale powieścią o Egipcie oraz o przemijaniu i o roli przypadku, o klęsce wzniosłych ideałów i tryumfie zła, a także miejscami powieścią o pięknie świata i o zaletach pracy na rzecz mądrości.

Faraon jest jedynym dziełem Prusa, w którym dochodzi do głosu konsekwentnie przedstawiany pogląd autora, że pod powierzchnia pozornie jawnych i łatwo wytłumaczalnych zjawisk historycznych kryją się tajemne mechanizmy i mroczne intrygi.

Znacznie ważniejszy od źródeł wiedzy Prusa o Egipcie wydaje się wpływ, jaki Faraon wywarł na ukształtowanie się w Polsce zainteresowania starożytnym Egiptem i uformowanie u nas kilku pokoleń jego badaczy. Można przypuszczać, że większość polskich egiptologów działających w w. XX przeszła przez lekturę Faraona i stamtąd czerpała inspirację do zajęcia się dawnym Egiptem. Co więcej, badacze ci, wprawdzie świadomi błędów i niedostatków wizji Egiptu u Prusa, zachowali mimo to ogromny sentyment do tej powieści i szacunek dla geniuszu autora.

Ważną kwestia jest zagadnienie recepcji Faraona w czasach po drugiej wojnie światowej. Jeden $z$ wątków szkicu Niwińskiego dotyczy upodobania Josifa Wissarionowicza Dżugaszwilego zwanego Stalinem do tej powieści ${ }^{39}$. Niwiński w przypisie odwołuje się do relacji Józefa Czapskiego, podobno pochodzącej od „pisarzy rosyjskich”. Przypis ów zawiera też odnośnik do artykułu Pawła Jasienicy w numerze 43 „Nowej Kultury” z r. $1956^{40}$ (nie znam tego tekstu). W Rosji mógł o gustach Stalina wiedzieć Wsiewołod Igoriewicz Awdijew ${ }^{41}$, a jeśli tak, to oczywiście musiało to wpłynać na jego komentarz do powieści Prusa w wydaniu rosyjskim (Moskwa 1951).

Z którym $z$ bohaterów powieści mógł się utożsamiać Stalin? Chyba nie $z$ naiwnym, impulsywnym Ramzesem XIII. Ideałem Stalina mógł być Herhor, „skuteczny” polityk o kamiennej twarzy.

Egiptolog Tadeusz Andrzejewski (1923-1961), który w okresie stalinowskim napisał komentarz do Faraona, był wtedy bardzo młodym badaczem. Niwiński twierdzi, że Andrzejewski w swoim komentarzu wdaje się w niezbyt ważne objaśnienia, chcąc uniknąć omawiania istotnych uchybień Prusa, a czyni to, by nie narazić się stalinowskiemu reżimowi. Wydaje się jednak, że nie dość wnikliwe przypisy Andrzejewskiego do Faraona nie wynikają z rozmyślnej tendencji, ale sa po prostu pobieżnym „odwaleniem roboty”. Konkretne wiadomości także się tam zdarzają, a dotyczą np. identyfikacji pojawiajacych się w Faraonie nazw geograficznych. Andrzejewski unika określenia „faraon”, zastępując je wyrazem „król”, woli też „powiat” od „nomu”. Mówi w duchu epoki o klasach społecznych, o małorolnych, średniorolnych i bezrolnych chłopach i o „wspólnotach wiejskich”, rzekomych pozostałościach społeczeństwa bezklasowego. W poprzedzajacych przypisy Objaśnieniach historycznych Andrzejewski stwierdza: „Pominięto tu krytykę realiów 
powieści, gdyż sprawa ta jest zbyt obszerna i wymaga osobnego opracowania" 42 . Tamże pisze, że „nawet docierając do najlepszych źródeł, nie mógł Prus ustrzec się pewnych błędów"43. Andrzejewski koryguje w przypisach niektóre anachronizmy Prusa. Nie wydaje się, by w Polsce w okresie stalinowskim nie wolno było w żaden sposób krytykować Faraona. Powieść historyczna w ogóle bywała czasem w krajach tzw. demokracji ludowej piętnowana jako przejaw eskapizmu, chyba że miała cechy poprawnej ideologicznie krytyki dawnego ustroju społecznego. Kulczycka-Saloni we wstępie do Faraona z wczesnych lat pięćdziesiątych starała się wykazać zbieżność przynajmniej niektórych wątków twórczości Prusa z doktryną historyczno-społeczną marksizmu, ale zaznaczała, że Prus w Faraonie reprezentuje burżuazyjny pogląd na ustrój społeczeństwa, co nie było komplementem ${ }^{44}$. Napisała ponadto, niezbyt zresztą trafnie, że Prus (tylko w epilogu, ale jednak!) „szukał wyjaśnień w dziedzinie metafizyki” ${ }^{5}$. Według tej komentatorki Prus „na tło odległych stosunków egipskich rzutował podstawowy konflikt swojej epoki”, a Egipt (rzekomo typowe państwo) przedstawiał ,jako maleńkie państwo półkolonialne" ${ }^{46}$.

Andrzejewski w komentarzu do Faraona wyraził pogląd o napływie do Egiptu niewolników w okresie wojen Nowego Państwa ${ }^{47}$. Nie wydaje się jednak, by ta opinia była zbyt głębokim ukłonem w stronę dogmatów nauki radzieckiej dotyczących tzw. formacji niewolniczej, ponieważ wspomnianemu twierdzeniu towarzyszy u Andrzejewskiego zastrzeżenie: „Zdaje się, że dopiero w tym okresie niewolnicy zaczęli stanowić bardzo ważny czynnik w procesie produkcyjnym" ${ }^{48}$. W rzeczywistości niewolnictwo nie odgrywało większej roli w gospodarce i życiu starożytnego Egiptu.

Relacje o upodobaniu Stalina do Faraona wydają się wiarygodne, ale nie znaczy to, by można było właśnie w Faraonie widzieć źródło imperialnych ambicji i monumentalnych budowli. Prus nie był ojcem Gułagu i Kanału Bałtycko-Białomorskiego. Te zjawiska miały wiele innych źródeł i wynikały $\mathrm{z}$ różnych okoliczności społecznych i historycznych.

Spostrzegawczy czytelnik Faraona może bez trudu zauważyć, że Prus nie komentuje wyraźnie samej zasady autokratycznego modelu władzy państwowej, jaki przedstawia w swej powieści. Opisuje szczególny przypadek starożytnej monarchii despotycznej, jaką był Egipt, ujmując się jednak za pokrzywdzonym ludem. W państwie faraonów posłuszeństwo jest „cementem” spajającym ludzi w funkcjonalną całość. Nie ma w takim modelu państwa miejsca na wolność jednostki. Prus formułuje wszakże zdecydowane postulaty dotyczące praktyki humanitarnej. Stawia absolutnej władzy faraona i egipskiej piramidzie urzędniczej wysokie wymagania moralne; zamiast bezwzględnej zasadniczości żąda zrozumienia i współczucia dla

T. An d r zej ew s ki, Objaśnienia historyczne. W: Pru s, Faraon (1952), s. 771. (W zamieszczonym w wyd. z 2014 r. wykazie publikacji o Faraonie wymienione są na s. 681 przedruki Objaśnień historycznych z r. $1950 \mathrm{i}$ z lat kolejnych, jednak z pominięciem r. 1952). Ibidem, s. 767.

44 Kulczycka-Saloni, Przedmowa, s. XII. (W wyd. Faraona z 2014 r. na s. 681 wymienione sa przedruki tej przedmowy z r. 1950 i z lat następnych, z pominięciem r. 1952). 
drugiego człowieka. Przy tym wkłada w usta kapłana Pentuera pogląd, że egipski stan kapłański, pełen rozmaitych nieprawości, jest mimo to „kagańcem, w którym płonie światło mądrości. Kaganiec może być brudny, nawet śmierdzący. Niemniej jednak przechowuje boski ogień, bez którego między ludźmi panowałaby ciemność i dzikość" (s. 427). W tym alegorycznym stwierdzeniu kryje się przekonanie autora, że trzeba się do pewnego stopnia zgadzać na zło towarzyszące (jakoby) nieodłącznie zjawiskom pozytywnym.

Faraon skonstruowany jest według zasady tragedii greckiej: od początku wiadomo, jak się dramat skończy. Rola przypadku i paradoksalność zdarzeń to stały element pisarstwa Prusa. Już nowela $Z$ legend dawnego Egiptu zapowiada tragiczny paradoks, wokół którego osnuta jest akcja Faraona. Głęboki smutek ogarnia czytelnika w obliczu przedstawionej w powieści klęski szlachetnych dążeń. Potrzebny jest zatem nie tyle happy end, ile grecka katharsis, czyli „uzdrowienie” (a nie „oczyszczenie”, wbrew mylnej, czysto etymologicznej, interpretacji, opartej na umiarkowanej znajomości greki) z przygnębienia towarzyszącego tragedii - wedle formuły Arystotelesa odnoszącej się do greckiego teatru. Prus rozumiał konieczność takiego zabiegu, stąd pojawienie się na końcu powieści pozornie nieorganicznego, refleksyjnego epilogu. Potem pisarz odstapił od tej koncepcji.

Przesłanie Faraona jest znacznie bardziej uniwersalne niż ukazanie dramatu jednostki. Związki z Najogólniejszymi ideałami życiowymi Prusa (1905) były już przedmiotem uwag komentatorki Faraona ${ }^{49}$.

Piszącemu te słowa wydaje się, że najistotniejszym zagadnieniem filozoficznym poruszonym w Faraonie, a najjaśniej sformułowanym w epilogu, jest nietrwałość struktur, nieodwracalność nawet przypadkowej ich destrukcji i nieuchronność przemijania. Pociechę przynosiła starożytnym Egipcjanom religia. Jednak Prus nie skłania się w tę stronę, czego wyrazem jest relacja o biegu myśli kapłana Samentu odkrytego w podziemiach Labiryntu. Akompaniamentem epilogu powieści jest pełna zwątpienia, pozornie hedonistyczna Pieśń harfiarza. Wprawdzie w treści Faraona mamy moment, w którym Mentezufis obiecuje Ramzesowi możliwość zatarcia błędów i ukazuje perspektywę bytu pozagrobowego, gdzie można dokonać niejako naprawy stłuczonych za życia dzbanów, jednak w zakończeniu powieści Prus nie podaje takiego remedium na tragiczne aspekty wszelkiej egzystencji. Na pytanie o sens zdarzeń autor Faraona udziela czytelnikowi odpowiedzi wymijającej, wskazując na strukturalny charakter naprzemiennego upadku i odradzania się społeczeństw (i państw) i zalecając kontemplację dziejów oraz poznawanie tajemnic mądrości. Nie pisze „dla pokrzepienia serc” i nie pozwala czytelnikowi całkiem otrząsnać się ze smutku i dostapić pełnego duchowego uzdrowienia, choć taki jest z pozoru cel epilogu.

Melancholijny epilog Faraona ujawnia głęboko pesymistyczny pogląd Prusa na życie, dostrzegalny zreszta już w autonomicznym opowiadaniu o wizji ukazanej umierającemu Ramzesowi XII przez Beroesa. Prus był pesymistą, co widać we wszystkich jego powieściach, a Faraon jest powieścią najbardziej z nich pesymistyczną. 


\section{Abstract \\ ADAM ŁUKASZEWICZ University of Warsaw \\ BOLESEAW PRUS' "FARAON" ("PHARAOH")-ANCIENT EGYPT AND POLISH CONTEXT}

Bolesław Prus' novel Faraon (Pharaoh), published in the year 1895, is based on political events in ancient Egypt in the 11th century BC, at the end of the Twentieth Dynasty. Prus was not a historian and apart from Pharaoh wrote no other historical novels. From the available sources he gathered information on Egypt of the pharaohs and inserted it into his masterpiece of literary fiction. His novel is superior to any other novel on ancient Egypt ever written. Regardless of numerous anachronisms and errors in description of the realities of ancient Egypt, the novel stood the test of time. Regrettably, it is little known in the world in spite of numerous translations into many languages. In Poland the book was subject to critical assessment by some reviewers for excessive didacticism and historical inconsistencies.

A new edition of Pharaoh with commentary was issued in 2014. It was prepared by Andrzej Niwiński, a professor of Egyptian archaeology at the University of Warsaw. The advantage of the edition is that it includes a collection of rare illustrations made 100 years ago by a famous painter Edward Okun (1872-1945).

Niwiński's edition contains many explanatory footnotes and appendices by the editor and by other contributors. These supplementary studies mainly refer to the origin of the novel and to Prus' readings. The volume also comprises a historical essay on the real history of the Egypt under the Twentieth Dynasty and an interesting text on the illustrations and their author. The footnotes and annexes are rich in valuable pieces of information. Nevertheless, they are not devoid of disputable matters. An important issue in Adam Łukaszewicz's article is a polemics with the editor's theory about Pharaoh being an allegorical novel which actually refers to Polish matters.

The author of the present paper who works in the field of Egyptian archaeology adds to Niwiński's commentaries some own observations on the realities described in the novel under discussion. 